University of Louisville

ThinkIR: The University of Louisville's Institutional Repository

Electronic Theses and Dissertations

1941

\title{
A history of the Danville Conventions, 1784-1792.
}

Paul Bingham Willingter 1916-2009

University of Louisville

Follow this and additional works at: https://ir.library.louisville.edu/etd

Part of the United States History Commons

\section{Recommended Citation}

Willingter, Paul Bingham 1916-2009, "A history of the Danville Conventions, 1784-1792." (1941). Electronic Theses and Dissertations. Paper 1928.

https://doi.org/10.18297/etd/1928

This Master's Thesis is brought to you for free and open access by ThinkIR: The University of Louisville's Institutional Repository. It has been accepted for inclusion in Electronic Theses and Dissertations by an authorized administrator of ThinkIR: The University of Louisville's Institutional Repository. This title appears here courtesy of the author, who has retained all other copyrights. For more information, please contact thinkir@louisville.edu. 


\title{
UNIVERSTTY OF LOUISVILE
}

A HISPOEY OF WHE DANVIIIE CONVENTIONS, 1784-1792

\author{
A Dissertation \\ Submitted to the Faculty \\ of the Graduate School of the University of Iouisvilie \\ Tn partial Fulfillment of the \\ Requirements for the Degree \\ of liaster of frts
}

Department of History

By

Paul Bingham Villirgter

Yenr

1941 
NAP OF SIULENT: Paul Bingham Willingter

TITIF OF THESTS: A History of the Danvilie Conventions, $1784-1792$

ARPEOVEI BY TEATNG CONTTTEE CORPOSED OF THE FOLIONING IEMERS:

NAME OF IIRECTOR:

DAT: famman, 442 
CFAPTIE I CENERAL CAJSES OF TEE NOVENENT FOR PAGE I SEPAEATTON OF KENTUCKY FROI VIRGINTA

SFAPTER II SPEIFIC CAUSES OF THE IOVENENT FOR SEPARATION FROM VTECINIA - TFE FIRST TPREE CONVENTIONS 


\section{CHAPTER I}

\section{GENERAI CAUSES OF THS DOV MENT FOR SEPAISATION OF KNTUCKY FRON VIRGINIA}

The admission of Kentucky int the American Union Tuie 1, 1792, is significant in the history of the United. States because Kentucky was the first state west of the Allegheny Mountains to be admitted. It was the fifteenth state to enter, beine preceded by vermont in 1791. Nost of the now states, twenty-eight to be exact, have been formed out of preexisting territories. Kentucky did not follow this most common proceedure. It is one of the five states which were formed by separation from other states. The separation from Virginia was dependent upon the consent of the mother state. In fact, three approvals were necessary before Kentucky could take her place as a member of the American Union - those of Kentucky, of Virginta, and of the Congress of the United States. These and varfous difficulties postponed admission until 1792.

The general causes of the movement for separation of Kentucky from Virginia include the following: 1) the general exporience of the pioneers on the frontier; z) Immigration from the East; 3) the problem of ownership 
of land; 4) the problem of distance from authority and the attending dangers and inconveniences; 5) the problem of trade outlets; and 6) the problem of defense from the Indians.

1) The general experience of the pioneers on the frontier from the beginning of settlement through the American fievolution had been such as to convineo them that they could take care of themselves. The frontiersmen had to meet situations as they arose and propose the solution which seemed best at that time. Hence, they early learned to do for themselves, and anything whjch tended to retard this process was resented. In Kentucky the actual movement for separation from Virginia began to develop as early as 1780, when Inadequate military supplies in the vest made defense from Indian attacks impossible. The movement was well developed aocut 1785 when two conventions had convened to consider a practical approach to the problem of defense in the West.

2) Increasea immigration from the East was another cause of the movement for separation. Iuring the American Revolution the success of George Rogers clark in ariving the 
British from the Ohio Valley seemed to promise safety to the West; and consequently a great wave of Immigration from the East flowed into the trans-Allegheng reglon. "The year 1779 and the succeeding brought upwards of twenty thousana people to rentucky." " so rapio. was the influx that the inconveniences of rempte legislation and executive authority scon began to be felt. Because of the great distance from western to eastern Virginia, and the difficulties of communication due to almost impassable mountains, elegates sent to Richmond from Kentucky ccunty soon lost touch with their constituents. The division of Kentucky into three counties in $1780,{ }_{4}$ ana its organization into a judicial district in 1782 did not satisfy the Kentuckians, nor did it lessen their determination to separate from the motrer state and seek admission into the American Union.

1. Temple Bodley, Cur First Great Hest (Louisville, 1938), Fils on Club Publication, No.36, p.I18 note

2. Tames R.Robertson, Petitions of the Early Inhabitants of Kentucky (Louis ville, 1889), Filson club Fublication, No. $27, \bar{p} .80$

3. William W. Hening, The Statutes of Virginia (Richmond, Va., $1819-23)$, Vol.10, p.315

4. Ib10. Vol.2, p.85 
3) The problem of ownership of land was one of the more important reasons for Kentucky seeking separation from Virginia. Iand was gold in early kentucky history. Many were the disputes that grew out of conflicting claims to land. One source of trouble was the absence of agencies, close at hand, in which land claims might be registered. Part of the problem was solved by dividing the larger counties into smaller units, thus providing more county seats for the registerine of land claims. Virginia also revised the colonial laws controlling the method of taking up land. The earliest land grants in Yentucky were made under royal authority, many of them under the King's Proclamation of 1763. All of these early grants were governed by laws of a very general nature. An act of 1748 , in order to prevent land fraud, stipulated that "no lands within this colony shall pass from one to another unless the same be rade by writing in the records of the general court, or in that county court where the land passed shall lie." Nevertheless, the general land laws of Virginia finally became so

5. Ib1d. Vol.7, pp.663-569

6.Ibid. Vol.5, p.408 
universally rerognized as inadequate that special steps wero taken during the latter days of the American Revolution to prepare a new land code. In Nay, 1779, the Virginia General Assembly passed a series of land laws which applied to all the western country including Kentucky. The first of these acts declared that "at the end of the war every of the sald soldiers, sailors, and marines, shall be entitled to a grant of 100 acres of any unappopriated land within this commonwealth." This act further states that "every soldier who enlisted into the corps of volunteers commanded by Colonel George Fogers Clark and continued therein till the taking the several posts in the Illinois country, shall, at the end of the war, be entitled to a grant of 200 acres of any unappropriated lands within this commonwealth."

Another act, adjusting and settling the titles of claimers to unpatented lands under the pesent and former government, previous to the establishment of the commonwealth's land office, said that all surveys made upon any of the western waters before Tanuary 1,1778, were nu11 and

7.Ibid. Vol.10,pp.:3-27 
void. However, 11 persons who, before Tanuary 1,1778, "settled upon any $u_{i}$.. ppropriated lands on the western waters, to which no other person hath any legal claim, shall be allowed for every family so settled, 400 acres of land....no family shall be entitled to the allowance Eranted to settlers by this act, unless they have made a crop of corn in that country, or resided there at least one year." Each such person was also given pre-emption right to purchase a thousand additional acres. ${ }^{8}$ This was done to discourage non-resident speculators.

The third of the 1779 land laws was "An Act for establishing a land office, and ascertaining the terms and manner of granting waste and unappropriated lands." $\odot$ These land laws finally resulted, in 1782, in the division of the western territory of Virginia into four judicial districts, one of which was the district of Kentucky. This, however, was necessary because of the growing need of judicial facilities for Kentucky.

In 1782 a petition sent to the General Asserbly

8.Ibid. Vol.10,pp.35-50

9. Ioid. pp. 5e-65 
of Virginia said that the 1779 land act creating a land office had made it posible for anyone "to purchase without cultivating, as much lands as he or she should think proper, which has been very injurious to the inhabitants, and of but small advantage to the commonwealth, it has prevented sufficient imigration." The memorialists further stated that:

"The persons granted land by the act of the May session in eighty-one, 10 in Consideration of their setting there since Seventy-nine, anc for other causes, have been prevented from acquiring such Lands by an Inundation of Warrants... but there being great Quantities of Waste and unentered lands yet in the cther couties in the District of Kentuckey which our Memorialists Conceives may be held in Reserve for the aforesaid setiers, as also for the Immediate Peopling of this country... Your memorialists wish to have their Locations secured to them who came early into this country, and many of them through illiteracy, and unable to ascertain the true meaning of the Law with the Troubles of Indians, have not Entered their Lands so special and precise as the Law Requires many of those Entries have been Reentered by others, which without the kind interposition of your House will produce Tecious Letigations." II

Thus it was possible for the land speculators to make their

10. Ibid. pp. 436,437

11.Robertson, op.cit.,pp.62-54 
claims before the new law was put into effect in Kentucky.

The people of Kentucky were also confused by the conflicting land claims of Virginia and the Continental Congress. Sir Wiliam Johnson, agent for the British Government, had, in 1768, negotiated a treaty at Fort Stanwix with the Six Nations Indians for a grant of land known as "Indiana." A colonizing company had been or ganized to petition the king for a grant of all of what is now west Virginia anc Kentucky east of the Kentucky River for a colony to be known as "vandalia." The king approved this grant, but the kevolution put an end to the land scheme. 12 The speculators then turned their attention to Congress, which, they doclared, had succeeded the Crown as owner of western lands. They held that Virginia's land claims were without legal basis and that, consequently, her land grants were questionable. These assertions appealed to the landless in Kentucky who used them as the besis for agitation against the virginia government in Kentuciry and in favor of erecting a new state under authority from Congress. 13

12. Bodley, Our First Great West, pp.35-54

13. Iemple Bodley, Introduction to Wllliam Littell, Political Transactions in and Concerning Kentucky (Louisvii10, 1926) Filson Club Publication, No.31, p. IV 
The discusition of the land question in Congress was prolonged and heated. When the thirtien colonies broke away from Great Britain seven of them had overlapping claims to western lands based on royal grants. These claims had been suspended by the King's proclamation of 1763. However, after the American Revolution the colonies revived their claims. Virginia had the largest claim, which included the present Kentucky, West Virginia, and the territory north of the ohio and east of the Mississippi. The ownership of such vast areas by a few states aroused ill-feeling among the ones which had no such nlaims. Maryland, a small state with no western lands, refused to ratify the Articles of Confederation until the landowning states agreed to surrender their claims to the new government. The Continental Congress urged the states to cede their western lands to the central government and promised that the territory so ceded wculd be erected into new states.

In 1780 Thomas Paine published a pamphlet entitled Puplic Good which gained wide circulation. He argued that vireinia did not own the western lands she claimed 
that the grants of land made by her were void, and that no one could de sure that his property as his own. Paine attempted to prove his argument $b$, citing the proclamation of 1763, claiming that it limited Virginia's western lands by the Allegheny Mountains. He favored the erection of a new state in the West. Paine's pamphlet caused some to favor separation of Kentucky from Virginia and admission into the Federal Jnion. George Rogers Clark stated in 1780 that certain "partizans in these cuntries are aga in Soliciting me to head them as (the)ir Governor General as all those from foreign states are for a new Government but my duty obliging me to Suppress all such proceedings I consequently shall loose the Interest of that party." 14 A Kentucky petition dated August $27,1782,{ }^{15}$ asked that Congress admit Kentucky finto the Federal Uion, since the harter under which Virginia claimed the western country had been dissolved and the land had reverted to the crown and that the Revolution had diverted all crown property to the central covernment (Congress). With the achievement of

14. Ceorge Rogers Clark Papers, 1771-1781, Edited by .T.A. James (Illinois Historical Collections, 1912, Springfield), Vol.VIII,p.453; original letter in Filson club Library 15. William E. Connelley and E.M.Coulter, History of Kentucky (The American Historical Society, 1922, New York), Vo1.I, D.224 
American independence, ownership of all vacant lands devolved upon the United States to the exclusion of state claims. This struck at all land titles in the west. One Galloway, in Fayette County, and George Pomeroy, in Jefferson, argued that all the Virginia patents were vold, and all her legislation and the procoedings of the land commission were nullities. Their following was the body of the landless and the land speculating. All landowners were alarmed. Galloway and Pomeroy were indicted under an ancient colonial statute of Virginia as "Divulgers of False News." 16 Thus the early movement for a revolutionary separation from Virginia made no progress, but other problems raised the question of separation with the consent of the mother state.

New York, whose claims rested on Indian treaties of ccuotful leqality, was the first state to surrender her claims. The Virginia Assembly on Tanuary 2,1781 , passed a resolution offering to cede to Congress the region north of the ohio River, provided she coulo retain the territory south of the river. This cession was refused. It was in

16.John Mason jrown, phe Pclitical jeginnings of Kentucky (Filson Club Publication Wo.5, Tohn P.Morton \& Co., Louisville, 1889 ), p.54 
the region to be retained by Vireinfa that the Indiana and Vandalia promoters were lookine for fortunes, and they had cained great influence in Congress. ${ }^{17}$ In $1783 \mathrm{~V} 1 \mathrm{r}-$ ginia again offered to cede its lands north of the ohio on the same terms as before. This cession was accepted and gave to the Confederation a vast public domain. In 1784 Thomas Jefferson proposed a plan (which was never put into effect) for the formation of states in the west. This plan embraced Kentucky, ${ }^{18}$ but the new ordinanco passed in 1787 applied only to the territory north and west of the Ohio.

4) The fourth reason for the movement for separation from virginia was the distance from chief state authorities and the aangers and inconvenjences in reaching them. The great distsnce from the State Capitol made communication with the state government slow, uncertain, and expensive. Land titles, trials, accounts, and claims were

17. Bodley, Our First Great West, p.179

18. Edward Channing, A History of the United States (Macmillan Company, 1905, New York), pp.537,538 
difficult to look after. Many land titles were lost because of the difficulties in registering claims. Travel between Kentucky and Virginia was diffinult and dangerous due to almost impassable mountains and hostile Indians. Immigrants entering Kentucky from Virginia and the arolinas came through the Cumberland Gap. Those entering from varyland and Pennsylvania came down the chio River. For many years, the "overland" route through the great wilderness was the only practicalle way of return because of the adverse current of the uhio. 19

An instance of the difficulties of the people of Kentucky due to their distance from the state capitol is Eraphical ly told in a diary of the period written by ceorge Rogers clark in which he gives the details of a journey to Williamsburg for the purpose of securing five hunered pounds of powder for defense in the West. Clark and Tohn Gabriel Tones were selected, at a general meeting at Harrodsburg, June 6 , 1776 , as delegates to the Virginia Legislature from Kentucky. The journey was made $b_{y}$ land over

19. Thomas speed, The Wilderness Road (Filson Cluo Puolication No.2, Tohn P. Norton \& Co., Louisville, 1886), pp.22, 23 
the wilderness Road. It was an extremely wet season, with mud or mountain most of the way, and constant danger from Indians, On the third day, Jones' horse gave out, and, since the country was so hilly, making it impossible for more than one person to ride on the one horse, the two men alternated. "The weather being rainy, our feet being wet for three or four days and nights without ever being dry, not daring to make a fire, we both got what hunters call iscela feet." "20 clark wrote lone afterwards that, on this jcurney, he suffered nore torment tran he had ever done before or since. Thus powder was obtained for the protection of the western settlements of Virginia, but only after the endurance of hardships and the ezpenditure of precious time.

The daners of the trip from eastern to western Virginia are well presentec in the journal of William calk, a Kentucky pioneer, who kept a day-to-clay record of a trip he made from his plantation in prince Villiam county, in eastern Virgini to Boone's fort on the Tentucky Fiver

20. William H. English, Conquest of the Northwest (Bowen-Nerrill Company, 1896, Indianapolis), Vol.I,pp.458-460 
The phraseology of this journal is crude and punctuation is almost entirely lacking. However, jt gives a more exact idea of the route followec by the first trailblazers then is found in any other contemporary document. It sketches the hardships endured by the heroes of the wilderness Red. On March 16,1775, Calk seys it "Snowd in the eavenine very hard and was very coald." On the l7th "the wind blows very hard." On the a3rd "we come to a turabel mountain t?at tried us almost to death to git over." On the zoth Calk's horse "got Scaro Ran away threw down the saddlebags and oroke three of our own powder goards."2l Thus the great distance and almost inpassable mountains between eastern änd western Vircinie made transportation and communication dificult and dangerous, and created a feeling which led to the movement for separate statehood.

5) The need of outlets for trade was a serious economic problem. It was difficult, if not irpossible, for eastern virginia to understand the problems of her cunties west of the mountains. The trade problem loomec large as a cause of separation. However, this problem did not

21. Iewis H.Kilpatrick, "The Tournal of William Calk, Kentucky Pioneer," The Mississippl Vailey Historical Review, Narch, 1921, Vol. VII, No.4, pp.365-367 
develop until Kentucky reised enough produce for export. By the treaty of 1763 France had given all British subjects the right forever to the free navigation of the Mississippi River through Louisiana to the sea. Just vefore the treaty was made France had secretly made another treaty transferring to Spain western Louisiana, Including New Crleans and the remaining area east of the Mississippl. When the colonies gained their independence, Spain claimed they had lost the right to use the river through her territory. 22 Spanish statesmen early furesaw that Spain's western hemisphere possessions, especially Loulsjana, would be endangered by a Erowing trans-Allegheny population. They therefore locked Ith extreme jealousy and fear upon the league of the thirteen young American republics. Througrcut the Fevolution, Spain, even after joining France in the war against Great Britain, refused to ally herself with the United States, or acknowledge their independence. With reference to them, her diplomacy was controlled by her desire to protect her louisIara possessions by extending her dominion over the eastern part of the Mississippi Valley, and maintaining exclusive

22.Bodley, our First Great West,p.22 
right to the navigation of the Mississippi kiver.23 After the American Revolution, with the aid of France, Spain tried to get the continental Congress to surrender to her the region between the Alleghenies and the lississippl as far north as the ohio. She failed in this, but, nevertheless, asserted her ownership of the lower Nississippl and forbade Americans to use it - arresting those who attempted. to do so, and confiscating their cargoeso

Since the cost of transporting their products over the moultains to Atlantic seaports was ereater than the price they could sell for there, Kentucky demanded that Congress force spain to open the Mississippl to western trade. Tohn Jay, later Confederation Secretary for Joreign Affairs, declarea Kentucky had a treaty right to freely navigate the Miss issippi. In 1780 he made a trip to Spain for the purpose of securing a loan for the struggling thirteen colonios. Don. Liego Gardoqui proposed that Tay offer the navigation of the Nississippi as a consideration of the loan. Said Jay: ".... the inhabitanss would not readily be convinced of the justice of being obligateo ejther to live without foreign comrodities, and lose the surplus of their productions, or be obliged to

23. Ibid. pp. 123,124 
transport both over rugged mountains and through an immense wilderness to and from the sea, when they daily saw a fine river flowing before their doors and offering to save them all the trouble and expense, and that without injury to Spain." 24

However, as Couverneur liorris wrote John Tay, many northeasterners falled to appreciate the value to the colonies of freely navigating the Mississippi. 25 These negotiations between Spain and the United States concerning the navigation of the Misstssippi continued after the treaty of peace was signed. The West was angered. almost to the point of secession when the Fast offered to suspend this navigation right in exchange for other commercial advantages. A sectional dispute developed. It was the commercial North against the agricultural south. The Virginia legislature by a unanimous vote instructed her representatives in Congress to oppose the Jay proposals. The Southern states lined up solidy against the North. The vote resulted in seven states out of the thirteen standing in favor of the Jay pro-

24. Francis Wharton, The Revolutionary Diplomatic Correspondence of the United states TWashington, covernment Printing office, 1889), Vol.IV,F.135

25. Jared Sparks, The Life of Gouverneux Irorris (Boston, 1832, Gray), VoI.I,pp.2.5, $2 \overline{2}$ 
posals; but as a vote of nine was required by the Articles of Feceration for the passage of important legislation, it ended in failure. But the mischief was done, the proposals had been sericusly considerea by Congress, and this was almost as strong a provocation to the Wiest as if the proposals had passed. James Wilkinson later secured trading privileges with the Sparish in New orleans at great personal profit. A Spanish conspiracy to detach the West from the United States developed out of the problem of trade outlets; but due to honest and sincere leadership in Kentucky it failed. 26

6) The problem of defense from the Indians was the most direct cause of the movement for separation from Virginia. United States law and custom recognized Indian tribes' right to land and government, unless their torritories were purchased from them. Kentucky had been purchased from the Cherokees oy Richard Henderson and the Transylvania Land Company, 27 but it was also claimed by the Shawnees who lived north of the Ohio River. The Shawnees

26. Connelley and Coulter, op.cit.,p.268 27. William S.Lester, The Transylvania Colony (1935) 
attacked the Kentucky setiements beginning in 1775. The Cherokees attacked mostly in Tennessee. During the Revolutionary war, the British encouraged Indian attacks in the West. George Rogers Clark's capture of Vincennes checked the Indian raids somewhat, but the continued until 1782 . After this date Kentucky was never invaded, but there was always the danger.

By the end of 1777 so many people had fled, or been killed or wounded in $K \in$ ntucky, that there were only three little forts left and barely 102 men and boys able to bear arms. ${ }^{28}$ Clark realized that defensive warfare by a few pioneers against thousands of Indians was hopeless. He knew the 3ritish from their posts at Detroit, Vincennes, and Kaskaskia, were equipping the savages and sending them to war. He believed tre only way to stop their ralds would be to reajuce these posts. Governor Patrick Henry of Virginia agreed and gave Clark II200 for expenses, and authorized hin to raise 350 volunteers. France beconing America's ally against Great Britain helped Clark's cause in the West. His surprize capture of Kaskaskia resulted in the French populated settlement

28. Main Butler, A History of the Commonwealth of Kentucky (Louisville, 1834, Wilcox, Dickurman \& Co.) p.95 
aligning themselves acainst the British. The vincennes people, learning of clark's capture of their brethern in western Illinois and the kind tneatment and freedom they had received, and learnine also that france had become America's ally, also threw off their British alleglance and acknowledged themselves citizens of Virginia.

When in 1778 Hamilton, the British comrander, at Ietroit learned the Americans were in possession of the Ill1nois towns and Vincennes, he resolved to retake the conquered territory. The French militia deserted the fort at Vincennes on learning of the coming of the British. Hamilton determined not to proceed against Clark at Kaskaskia until spring because "late rains have swelled the rivers." Clark resolved to take advantage of Hamilton's disarmed situation in Vincennes. His surprizing recapture of Vincennes lowered British prestige amone the Indians. Niany of the Indian tribes from the Ohio to the Great Iakes made peace and scught alliance with Clark, except the shawnees of southern onio. A Ereat westward flow of people followed these developments, especially to Kentucky. Clark next dotermined to capture Detroit and gain control of the creat Lakes. He received a 
letter from Governor Henry saying that a reinforcement of 500 men had been sent him. If he waited for these troops to arrive, the enemy at Detroit would get strengthened. A council of Clark's men decided to wait for the troops, ana Detroit was not attacked. $2^{9}$ Clark's force was aisoanded in 1780. Due to military problems arisine everywhere, clark never found it possible to attack Detroit. For years, consequently the British continued to encourage Indian resistance from that fort. "From what is now known from the British archives of conditions then existing at Detroit, it can haraily be coubted that clark's plan... woulo. have succeeded. $30 " 1$

The cherokee wars (1776-1781) were a result of the urgings of the Shawnees and other northern Indian tribes that the cherokees resist the continued encroachments on their lands. The Cherokees, weakened by the refusal of the creeks to help them, were dofeated by the caroIiras aided by congress. They purchased peace from Georgia, the Carolinas, and Virgjnia in July, 1777, by extensive land 29. Bodley, Uur First Great West, pp.99-119 30.Ibia. pp.119,120 
cessions in the Carolinas. In 1779, the Cherokees allied themselves with the Northern Indjans to aid Hamilton in his campaign agalnst clark. Some of Clark's forces were sent to destroy the Cherokee towns and they carried off great quantities of supplies placed there by the British. But the Cherokees reestablished themselves farther south and continued to worry Kentucky. 31

The greatest battle of the Revolution in Kentucky was $y \in t$ to de fought. In the fall of 1782, an Indian and British invasion of Kentucky was organized. Clark prepared to attack, whereupon most of the 1100 mustered Indians turned back. However, 300 Indjans plus some rangers from Detroit crossed the Ohio Iver August 19,1782. They attemptec to take Bryan's Station by surprize but, failing in that began preparations for a siege. Runners warned the other stations but without raiting for Colonel Logan, the Kentuckians set out in pursuit of the Indians who had unsussessfully tried to storm the fort, and who had left a plainly marked trail, the purpose of which was to lure the pursuers into a trap. 32 The resulting Battle

31.R.S.Cotterill, "The Cherokee Wars", Dictionary of Amertcan History, (1940), Vol.I, p.353

32. Fieuben T. Durrett, Bryentis Station (F1lson club Publication No.12, John ?. Morton 3 Co., Louisvi11e, 1897), p.227 
of the Blue Licks (1782) was a most disastrous defeat for the whites. It turned out to be the last battle of any consequence between the Kentucky settlers and the Indians. 33 But for a time the Kentuckians fearea that this success of the British and the Indians wolld lead to renewed attacks which might destroy the settlements completely. Clark determined to put Kentucly in a state of defense and to carry the war into the Indian territory. An attempt to fortify the mouth of the Licking River failed. However an expedition to the north of the ohio was fitted out during september and October (1782). The spinit of the people was high, but it was difficult to gather together the proper provisions and equipment due to the low state of Virginia's credit. Clark provided flour for this expedition by the exchange of 3,200 acres of his own land. By the early part of November he had collected two divisjons of troops at the mouth of the Licking River composed of 1,050 men, all mounted, and eager to avenge the disaster at Blue Licks. After a march of six days, Chillicothe was reached, but the Indjans made their escape before the whole army could give battle. Chillicothe and

33. Bennett H.Young, History of the Battle of Blue Licks (Louisville, 1897, John P.Norton \& Co.T preface 
other villages of the Shawnees were destroyed. Logan destroyed a British trading post. The peace of 1783 meant nothing to the Indians, and, with the subsequent machinations of the British in the Northwest, least of all did $1 t$ mean peace with the western settlers. Many campaigns were yet to be carried on against the Indians, and, in fact, thetr power was not broken completely until the end of the War of 1812, when Tecumseh and his Northwest Confederation were destroyed. 34

The movement for separation from Virginia began in November, 1784. In this year Colonel Benjamin Logan, military commander of Iincoln county, heard that the cherokee Indians were planning a great invasion of the southern frontier of Kentucky, while another band was making ready a campaign against the northern settlements. This information reached some of the militia officers at Lanville, the capital of the District of Kentucky, shortly after the general court had adjourned and while many of the prominent people were gathered. An informal meeting of Kentucky military officers was called by Colonel Logan to discuss measures of de-

34. Connelley and Coulter, op.c1t.,op.186,187 
fense. The only contemporary account of the discussions at this gathering is in a letter to Colonel Arthur Campbell from Ebenezer Brooks. 35 The letter says that Colonel William Fleming was elected chairman and Christopher Greenup, clerk. Ebenezer Brooks proposed a separate Eovernment for Kentucky. Colonel Logan favored surprising the Indians by offensive action. But since there was no declared state of war, the county lieutenant possessed no statutory authority to call out the men or take measures to equip and supply them. An eyccutive or military act required the santioning of the Governor of Virginia at Williamsburg. The meeting found it impossible to take the offensive action suggested by Logan. The counter-attack upon the Cherokes could not be made. This November conference, called for a single military purpose bruadened into a consideration of the general political situation. Not a ferry could be established, a village incorporated, or a necessary magisterial office created without the ruinous delay and cost attending a journey of petitioners to the eastern limits of Virginia. Although the rumor of Cherokee attacks was proved false, the meeting de35. Temple Bodley, History of Kentucky (Louisville, 1928, S.J.Clarke Co.), pp.354-356 
cided to call a convention to meet "on the fourth Monday of next month (December) which may be an introduction to important events." 36

In 1783 when Congress received Virginia's cession of western territory, it appointec a comrission to treat with the Indians for lands in the ceded territory. It also dischärged all its Continental troops in the west save those at West Point and Pittsburgh. These two acts of Congress proved disastrous for the Kentucky people. The Indians became confident of their ability to maintain their ground, and decidecly more hostile. The immigrants to Kentucky found themselves in almost constant dread of Indian rajds. Thus the disordered state of affairs in kentucky, the ever-present danger from the Indians, and the serious inconvenience of government from the distant state capital at Williamsburg plainly called for a separate government for the District.

36. Williams Littell, Political Transactions in and Concerning Kentucky (Reprint, Filson Club Publication No.3I), p.12 


\section{SFAPTEF II}

SEECIFIC CAUSES OF THE MOVANEN FOR SUPAEATION FROH VIEOTRIA TEE FIRST TIREE CONVANTIONS 


\section{CFAPTER II}

SPECIFIC CAUSES OF THE HOVEMENT HOE SEPARATION FROM VIRGINIA - THE FIRST THREE CONVZNTIONS

The purpose of the previous chapter was to set forth, in a general way, the fundamental causes of the movement for separation from Virginia. The present chapter is concerned with the more immediate causes of the separation movement as set down in the first three Kentucky conventions.

The purpose of the first three conventions was to consider the immeciate problems of Kentucky as a part of Virginia, and to make some practical suggestions for the solution of these problems. A military necessity set of the movement for separation from Virginia. The Kentuckians were unaple to provide for their own defense. The conventions were anxious that the will of the people should be clearly represented. The question of separating from the mother state was considered too serious to allow any doubts to exist as to what the Kentuckians wished. It was considered important, therefore, that the people of Kentucky be educated as far toward the point of unanimity as possible. Diring the first three conventions, the rentuckians came to regard 
their political privileges as of some importance in influencing their living. So cautious were their proceedings that it was not until the third convention that the Virginia Legislature was formaliy informeo of the cesire of the Kentucklans to sepam rate from the old Dominion. Interest in informing the publio on the d velopments of the conventions resulted later in the founding of the first Kentucky newspaper.

The immeciate causes of the calling of these three conventions were: the rumored Indian incursions; the increaso in population and the fact that Virginia was unable to rule effectively and wisely so large a number of people so far away and separated by almost impassable mountains; the fact that it was necessary to get the permission of Richmond to do the most minute things; and the fact that Virginja nould not possibly completely understand the problems of a part of her state so far away and with which it was so difficult to communicate.

Governor Don Esteban Miro, governor of Iouisiana, Issued a call for all Southern Indians to attend a conference at Pensacola in Tune, 1783. Miro said to the Indians, in open treaty, "Do not be afraid of the Americans. You, our 
brothers the red men, are not without friends. The Americans have no ling, nc are nothing of themselves. They are like a man that is lost and wandering in the woods. If it had not been for the Spanish and French, the British would have subdued them lone ago.l Governor Miro held another congress of Southern Indians at pensacola in June, 1784. He told the Indians that:

"The King of Spain desires the friendship of all red nations, and looks upon them as his brothers. No other nation except Spain can now supply your wants. In a short time, the Spaniards expect to be at war with the Virginians, and we look upon the Indians as our allies to aid and assist us when called upon."2

These speeches indicate that the Spanish in Lulsiana wero attempting to stir up the southern Indians against the Americans in the west. It is possible that Colonel Logan received notice of these pensacola conferences and warned the Kentuckians accordingly. However, there is no oirect evidence to prove that this was the case. In any case it appeared to

1. American State papers, Indian Affairs, Vol.I, quoted in John P. Brown, old Frontiers (Kingsport, Tenn., 1938, Southern Publishers, Inc.), pp.121,122

2. N.C.Colonial Kecords, 17:74-87, quoted in Brown,op.cit.,p.224 
Logan that the threatened danger would best be averted by Kentucky striking the first blow, and that the Cherokes should be attacked before they were ready to take the warpath. But since there was no declared state of war, the county lieutenant possessed no authority to call out the militia. These powers had lapsed with the peace with Great Britain. There was no public machinery other than the meager authority of the county justices, Iimited as it was by the statutes erecting the counties. An executive or military act required the sanction of the Virginia governor. 3 Therefore, it was imposible to take the action sugested by Logan. Whereupon, a conference was called in Novemoer, 1784, to take into consideration the military situation of the District of Kentucky. The result was an unaivus conviction that the time had come when Kentucky should be erected into a separate and independent state, and be incorprated into the Federal Union with a local Eovernment of its own. Thus was set in motion a movement of events and persons that was to give birth to ten Danville Conventions which were to result in separate statehood for Kentucky in

3. Humphrey Narshall, History of Kentucky (Frankfort,1812, Heiry (Gore), p.225 
Tune, 1792 .

The First Convention, like all succeeding ones, met at Danville, to which newly established "station" the District Court had removed its sittings. The session lasted ten days (December 27,1784 to January 5, 1785). William Fleming, an influential citizen, presided, and Thomas Todd, later a Justice of the Supreme Court of the United States, was clerk of this convention. The majority of the delegates were natives of Virginia and the procedure was in strict conformity with parliamentary law.

The convention resolvec"that the remote distance of this territory from the government of virginia subjects the inhabitants to a multitude of civil and political inconveniences that are increasing dajly" and "that it be recomrended to the inhabitants of this territory to seriously consider if $1 t$ wculd not be advantageous to ask of our national government that this territory be created into $\Rightarrow$ new atate, confederated with the other states." Whereupon it was recommended that the inhabitants of the district elect a convention "whose opject shall be to enquire if the proposed separation be really necessary, useful, and indis- 
pensable."4 The convention felt that this step would not offend Virginia, since her constitution, adopted in 1776, provided for the establishment and eovernment of new territories west of the Allegheny Nountains: "The western and northern extent of Virginia shall stand as fixed by the charter of James I, 1609, and by the public treaty of peace between the courts of Creat Britain and France, 1763, unless by act of legislature one or more territories shall hereafter be laid of $f$ and governments estaolished westward of the Allegheny lountains." 5

The delegates to the First Convention, being but representatives of their respective militia companies, chosen without formal warrant of law were careful not to transcend their special powers, and contented themselves with a recommendation that a convention be held in the spring of 1785 to consider the propriety of an application to the legislature of Virginia for an act establishing the State of Rentucky. It was resolved"that all the counties in this territory shall have an equal right to representation in the choice of their

4. William Fleming, "Hinutes of the First convention, held at Danvilie, in the Territory of Kentucky, December 27 , 1784" Lou is vilie Nonthly Magazine, Narch,1879, pp.124,125

5.Hening, op.cit.,Vol.IX,p.118 
members according to the number of inhabitants of the different counties." It was "expressly and particularly enjoined upon the good people of Kentucky to select for members representing their counties men of the highest character and possessing the most varied ability and extensive knowledge." 6

Fortunately the anticipated. Indian invasion did not occur. However, the attention of the Kentuckians was called to the existing inconveniences of being governed by Virginia. Luring the four months from the adjournment of the First convention until the election of the second, the people of Kentucky were 1 iven an opportunity to discuss the specific question of stategood and to determine on representatives who would carry out their views. A movement was begun that was eventually to result in statehood.

The second Convention met in Nay, 1785. Samuel McDowell (father of Ir. Forraim McDowell) was elected president, and 'thomas Todd was chosen clerle. This comoination of officers was followed in the eight succeding conventions. The Second Convention was composed of twenty-cight members chosen

6. William Flemine, op.cit.,p.125 
in the following proportion: twelve from Iincoln County, eight from Fayette, and elght from Tefferson. There were no important election contests. Other important merbers were: George Iuter, Chief Tustice of the District, a Vireinian of Scottish origin, who later supported Patrick Henry in opposition to Virginia's ratfication of the Federal Constitution; Christopher Greenup, later one of Kentucky's first two rembers of the United States Flcuse of Representatives, $\mathbf{8} 1 \mathbf{8 0}$ elected covernor in 1804; James Speed, a Virginian of English descent, who was one of six brothers who served in the Revoiutionary War; and Tames Garrard, later a covernor.

This Second Convention unanimously passed resolutions calling for Kentucky's separation from Virginia and admission into the Confederation. Thereupon a petition was ordered to be prepared and sent to the Virginia Assembly praying for the state's consent, and also an adoress to the Kentucky poople. However, they "determined not to proceed in a matter of such magnitude without apeated appeal" to the people of Kentucky, and consequently, the election of another convention to meet the following August was recommended. It was resolved "that the election of deputies for the proposed convention oucht 
to be on the principles of equal representation" and "that the petition to the assembly for establishing this district into a state, and the several rosolves of the former and present convention together with all other matters relative to the interest of the district be referred to the future convention, that such further measures may be taken thereon as they shall judge proper." $" 7$

The ioea of equal representation in proportion to population represents a departure from the Vireinia system of $r e p r e s e n t a t i o n$ by counties regardiess of population.

The cidress "To the General Assembly of Virginia", wich was never delivered to that auguet body, was a plain eppeal for separate statehood.

The address "To the Inhabitants of the Iistrict of Kentucky" stated that a convention should be authorized to assemble and adopt a constitution and form of government. The Virginia acts which were in force at the time of separation

7.Iittell, op.cit.,p.6I 
woulo continue in force until altered by Kentucky. The District was willing to assume its just share of the VirEinia state debt. Finally the petitioners desired that Kentucky "Be taken into urion with the United States."8

The address "To the Inhabitants of the District of Yentucky" said that several laws have passed the legislature of Virginia which "are particularly oppressive to the people of this district," and that "from our local situation, we are deprived of many benefits of government." The petitIon proceedid further to enumerate the grievances of the Kentuckians:

"We have no power to call out the militia. We can have no executive power In the district, either to enforce the execution of laws, or to grant pardons to oojects of mercy. We are ienorant of the laws that are passed until a long time after they are enacted; and in many instances not until they have expired; by mears whereco penalties may be inflicted for offenses never designed, and delinquents escape the punishment due to their crimes. We are subjected to prosecute suits in the Hieh Court of Appeals at Richmond, under every disadvantage, for the want of evidence, want of friends, and want of money. our money must necessarily be drawn from

8. Ibid. pp. 63,64 


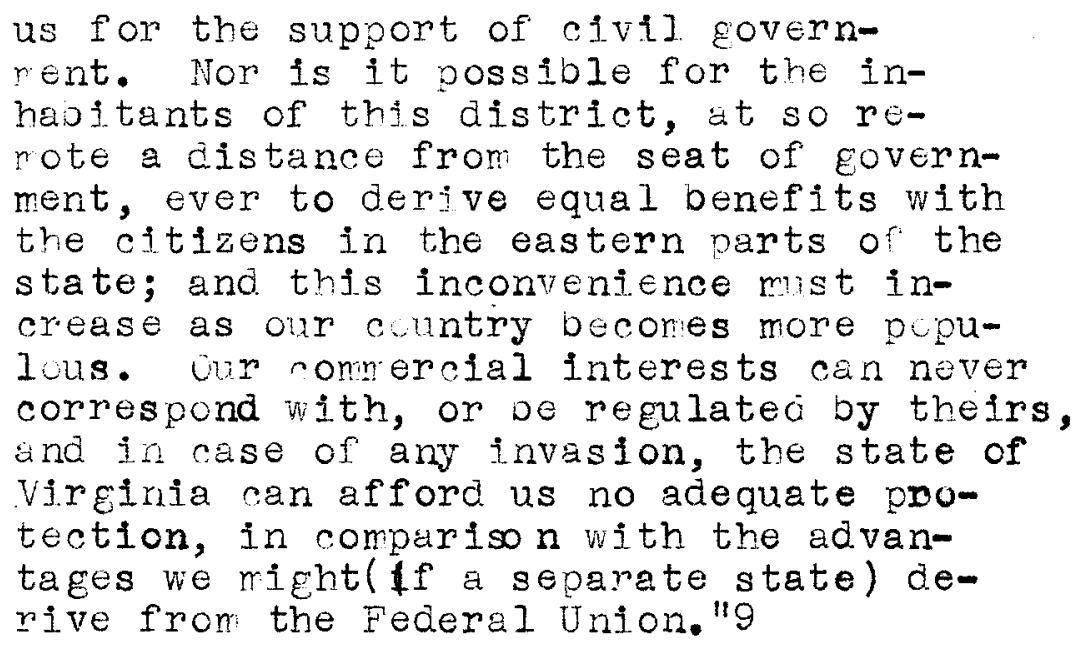

The address related that the last Vircinia Assembly passed an act putting the revenue law in foree within the district, compeling the entuckians not only to pay a very consideraole part of the tax for the support of civil government in virginia, wut also to pay another tax to support the supreme court a d other offices in the district. The opinion of the Convention was that the additional expenses of statehood of a eovernor, council, treasurer, and delegates to congress would de less then the expense of bejne a part of virginia. Therefore, no adaitional taxation of the people would de necessary. 9

9.IDid.pp.63,64 
At this time there was no printing press 10 west of the Alleghenies. Therefore, in order to inform the people of the proceedings of the second Convention, the clerk was directed to transmit to the office of each county court copies of the petition to the legislature of virginia and the address to the people of the District, with directions to post them on the court-house doors, together with the time of holding the elections for the August convention. The elections were to be held at the court-house on the July court day of each county. Iircoln ourty was to elect ten members to the convention, Fayette eicht, and Jefferson a nd relson six each. It was hoped that the interest of the people of Kentucky would be further aroused and that the AuEust convention would be even more representative of Rentuoky opinion concerning separatio from Virginia.

The third convention mot August 8,1785, to ratify the petition "to the Ceneral Assemily of Virginia." Twentysix delegates attended. Among the leading mempers were George Muter and Harry Innes, who were appointed to take the

10. The first newspaper in Kentucky, The Kentucky Gazette, was established at Lexington by Iohn Bradford in August, 1787. 
Virginia petition to Richmond, and to use their influence in securing its passage. Another prominent member was Tames Wilkinson, a Marylander of English origin, who came to Kentucky in 1784 with the tide of immigration following the war, formerly an offjcer in the continental Army, and a man of fine address, of great talent, and of urtiring idustry. ${ }^{11} \mathrm{He}$ had defeated Humphrey Varshall as dulegate in the convention from Fayette county by an election trick, so it was saja.12

The Third convention followed its predeessor in declarine "that the situation of this district, upwarcs of five hundred miles from the seat of the present government with the intervention of a mountainous desart of two hundrea miles, passed only at particular seasons, and never without danger from hostile nations of avages, precludes every idea of a connection on republican principles and originates many grievances."I3 In even greater detaj this new petition listed these grievances, stating that the con-

11. Connelley and coulter, op.c1t.,p.231

12.Temple 3odley, Introduction to Littell's Political Transactions, p.xi

13. Iittel1, op.cit.,pp.66,67 
nection with irginia made it impossible to appeal to executive authority in ases of emergency, $a n d$ thereby "subjects the district tc continued hostilities and depredations of the savages." 14 Condemned persone, worthy of pardon, were subjected to unnecessary imprisonment. Adequate representation in the Virginia legislature w difficult and precarious, as no person properly qualified, ould be expected tc undergo long, dangerous, expensive, and fatiguine iourneys across the mountains. Jany lews operated and expired before they reached the district. Sheriffs and nlerks were unable to comply with many of their duties. The poor were unable to avall themselves of needed court services. Cther grievances resulted fror laws which were contrary to the fundamental principles of free government, such as the law for the establishment and support of the district curt which obliged the Kentuckians to buld their own court-house, iail and other ouflaings, by a special poll-tax imposed upon the inhabitants of the district, while several court officers were unpaid. The law wich imposed a tax of five shillings per hundred acres on lands previously sold, and directed payment at Fichmond, oefore the patent would be

\section{Inid. 0.68}


issued was considered to be "subversive of justice." Another oujectionable law prohioited punishment of a savage who attacked Kentucky and escaped to the north of the ohio.

The Third Convention, in the petition to the VirEinia Assembly, quoted the Virginia Bill of Rights to support, the Eeneral principles on which they stood; "that ail men are born equally free and independent, und have certain natural, inherent and inaljenable rights; rone which are the enjoying and defending of life and liberty, of acquiring, possessing, and protecting property, and of pursuing and ootaining happiness and safety." It resolved to apply to the Vireinia Assembly for an act to separate Kentucky from Virginia "forever" on "terms honorable to poth and injurious to neither." 15 This resolution was agroed to by all the merbers present. Having resolved for separation, the convention next turned its attention toward methods for carryine it cut. This resulted in the preparation of two new adaresses: one for the people of Kentucky anc one for the legislature of Virginia. The purpose of the address to the inhapitants of the Distrint of rentucky 
was to keep the populace informed on and interested in the convention procecdings. The adaress to the General Assembly of Virfinia out ined the exact mode of procedure of separation.

The address "to the honorable General. Assembly of Virginia" did not recite in detail the causes for separation from Virginia. Briefly statine that "our sequestured situation from the seat of govenment precludes erery idea of a connection on republican principles," 16 the convention prayed "that an act may pass at the ensuing session of assembly, declaring and acknowledging the sovereignty and indipendence of this district."16 The convention asked Virginia to a gree "to a dismemberrent of its parts, in order to secure the happiness of the whole."16 It felt that this action vould carry further the olessinge of the Arerican frovolution: "We firmly rely that the undimimished luster of that spark whinh kindled the flame of liberty, and guided tho Unitied states of Anerica to peace ano independence, will a rect the honorable body to wom we appeal for redress of mamfest grievances, to morace the singular occasion reserved 
fot them by djvine providence, to originate a precedent which which may liberalize the policy of nations and lead to the emannipation of enslaved ililions." 17 ceorge Duter and Harry Innes accordingly delivered this address.

The adoress to the Kentucky people painted a picture of the coming destruction from impending Indian raids unless Kentucky did sorethine about it. It reported that already "blood has been spilt" in the district. "These aro causes sufficient to rouse our attention, that we may be prepared not only to defend but puntsh those who unprovoked offend us. We seem patiently to await the stroke of the tomahawk. Have we forcot the surprize of Bryan's station? Iet us rouse from our lethergy, lot us arm, associate, and emoody." The comandine officers of the counties of the aistrict were ordered to discipline the militia, make olans for the defense of the district, and plan to carry expediticns against the hostile nations of Tindians. 18 Tre convention assumed in the address to the people certain powers that approached full government responsibility. There is also evidenced a strain of growing

17. Ioid..p. 70

18. Ioid. $2 p \cdot 71,78$ 
impatience. Since the action of this convention was supposed to secure final results, there was no call issued for a new convention. It was assumed that the next assembly would be a sovereign convention, called by the authority of Virginia, whose outy it wculo de to provide a constitution for Kentucky.

These two addresses were written in a very ambitLous style, charanteristic of the pen of General Wilkinson. Humphrey Narshall sccuses wilkinson of a premeajtated alliance with Spain. Says Marshall:

"In reviewing thj address, the mind is unavoidably arrested by one idea which it suggests - lthat the situation of the country was irreconcilable to a connection with any oormunity beyond the Appalachian fontains - other than the Federal Unjon.' The inference seems to be invited that a connection on this side of those muntains was not of so inflexible a nature."19

Says John Brown, on the other hand,

"What aver may have been his subsequent intrigues, it is absolutely certain that at that time Wilkinson had never met a Spanish official, or been within a thousand miles

19. Humphrey Varshall, op.cit., p.250 


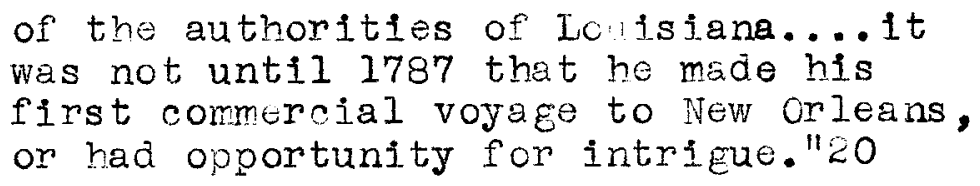

The writer is inclined to accept the interpretation of Brown that the address meant that the Third Convention considered the military and political situation in Kentucky sufficiently serious to warrant irmediate action. The writer believes that at this time Tames Vilkinson had not yet met a Spanish official, but that he was feeling out the problems of the West, and planning how he culd profltably engage himself. The address to the Kentuckians shows Wilkinson to be a clever propagandist. The fact that he oja not make reference to Kentucky's admission into the Confederation is significant. This step would have spoiled his plans. He, himself, not the Confederation government, wanted to medale in Kentucky's proolems for his own personal profit and glorification. To Wilkinson independence and sovereignty meant that zentucky Wculd separate from Vireinia but not seek admission to the Confederation. He would "take care of"Kentucky after she were "Independent and sovereign." 21

20.Brown, op.cit., p.71

21. Thomas Mr. Green, The Spanjsh Conpiracy (Cincinnati, 1891, Robert Clarke \& $\overline{\mathrm{Co}} ., \mathrm{J}, \overline{\mathrm{p} .62}$ 
OAPTER III

STATEHOOD DEFERRED 
CHAPTER III

STATEHOCD DAFIRRED

There seems to have been little opposition to making Kentucixy a separate state. In view of the reported discontent of Kentuckians over their inability to trade at New Orleans, however, some feared kentucley might separate from the United States. Washington wrote: "There are many ambitlous and turbulent spirits among its inhabitants who, from the present difficulties in their intercourse with the Atlantic States, have turned their eyes to New Crloans, and may become riotou and ungovernable." I Witing to Thomas Tefferson from lount Vernon, September 26, 1785, he said,

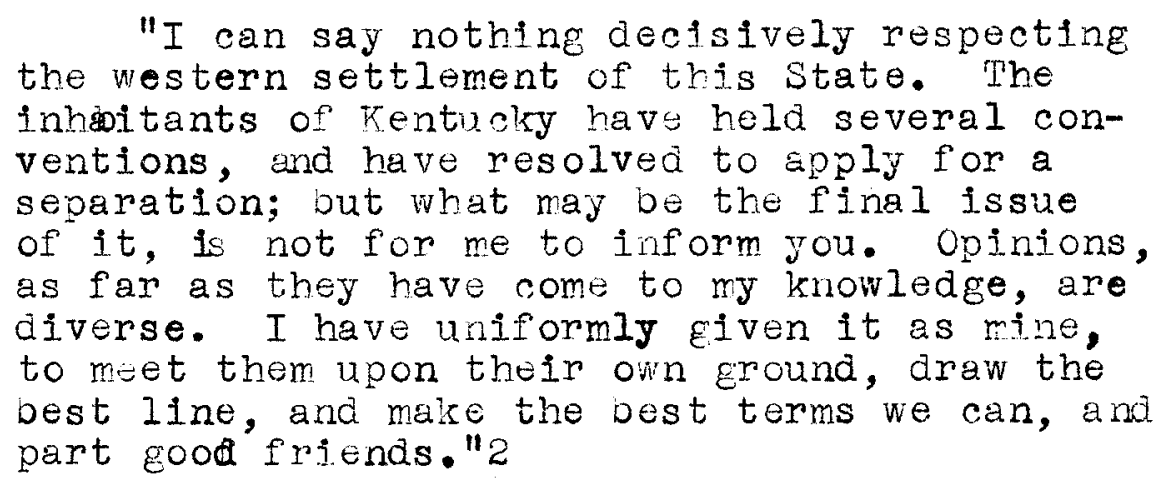

1. The Writings of George Washington (Boston, 1835), Edited by Tared Sparks, Vol. IX, p.180 (Letter to Henry Lee, Tuly 26, 1786 )

2.Ibld. Vol.IX, 0.134 
Others also feared Kentucky's separation from the Confederation. In a lettor witien to Archibald stuart from Paris, France, January 25, 1786, Thomas Jefferson said,

"I fear from an expression in your letter that the people of Kentucke think of separating not only from Virginia (in which they are right) but also from the Confedracy. T own I should think this a most calamitous event, and such an one as every good citizen on both sides should set himself against. our present federal limits are not too large for good government, nor will the increase of votes in congress produce any 111 effect. on the contrary it will drown the little divisions at present existing there. Our Confederacy must be viewed as the nest from which all America, North and south, is to oe peopled. We should take care too, not to think it for the interests of that great continent to press too soon on the spaniards. Those countries cannot be in better hands. Miy fear is that they are too feeble to hold them till our population can be sufficiently advanced to gain it from them piece oy piece. The navigation of the Iississippi we must have. This is all we are as yet ready to rocelve." 3

James Monroe, while not entertalning a pronounced untagonism to rentucky statehood, believed that the admis-

36 The Writings of Thomas Tefferson (1904), Edited by Paul Leicester Ford, Vol.V, pp.74,75 
sion of western states should be restricted as much as possiole. Fe was not actuated by any hostility to the hest; out, rather, he feared the dirinj hing impurtance of Vireinia as western states were admitted. Speaking of the Kentuciry situation, he satd: "My opinion is we could so model cur reulations as to accomodate our covernment to their convenience, and unquestionably the more we diminish the state, the less consequence we will have in the union."4 This opinion was expressed in August of 1785. Shontly thereafter lonroe made a visit to Kentucky. He later changed his views, and contemplated for a time casting his lot with the Kentuckians. Instead of Delieving that the separation of Kentucky from virEinia woud lessen the latter's importance, he now thourht that Kentucky should become a state, among other reasons, because, as a state, she would add her power to virginia's influence in the Union.

James hadis on had warned that "no interval whatever

4. The Wrjtings of Tames Monroe (New York, 1898-1903), Edited by S.M.Hamilton, VoI.I, P.TOr

5. H.T.Turner, "Western sta te-Naking in the Revolutionary tra", American His torical Review, Vol.I, pp.262,263 
should be suffered between the release of our hold on that country and its taring on itself the obligations of a member of the federal body. Should it be made a separate state without this precaution, it might possibly be tempted to remain so, as well with regard to the U.

It is perhaps signiflcant that no mention of an intention to enter the Union was made in the address to Virginia which vilkinson wrote and which vuter and Innos carried to Pichmona.

In view of all these statements it is easy to understand why Virginia was willing to grant separation to Kentucky - she was anxious to keep Kentucky in the Unitcd States.

When George Nuter and Harry Innes appeared before the Virginia legislature at its winter session of 1785-6, they were accorded a favorable hearing. A b1ll was quickly passed for "the erection of the District of Kentucky into an Independent State" (Tanuary 10,1786) ${ }^{7}$, more often referred to as 6. The Writings of James Madison (New York, 1884, F. Worthington, 7. Hening, ㅇ․cit., Vol.XII, pp.37-40 
the "First Enabling Act." Tris act specified that in the follcwing August, on the respective court days of the counties within the district, five representatives should be elected $b$, the free male inhabitants of each of the seven counties (Jefferson, Nelson, Fayette, Bourion, Lincoln, Madison, lercer). The act was to be read each day for five days, 1rmediately preceding the election, at the door of the courthcuse, or other convenient place, and two copies were to be posted at the plane of election twenty days before the elcetion, in order that the people might be very well informed on so important a matter. The duly elected representatives should be present, a president and other proper officers were to be chosen and proper rules of proceeding adopted. The purpose of this convention would be to determine whether or not It was the will of the people of the district to be erected into an independent state on the terms and conditions of the Act.

The act specified "that the boundary between the proposed state and the state of Vireinia, shall remain the same as at present separates the district from the residue of the commonwealth." The future state "shall take upon itself 
a iust proportion of the public debt" of Virginia. "All private rights and interests in lands within the district, derived from the laws of Virginia, prior to such separation, shall remain valid and secure under the laws of the proposed state." Lands owned by non-resident proprietors within the proposed state should not at any time before or after statehood be taxed higher than the lands of residents. Grants of land issued by the proposed state shuld not interfere with any land warrants issued from the land office of irginia at any time in the past up to and including september 1, 1788. Virginia retained the right to claim all the unlccated lands within the said district, which stooo appropriated by the lavis of Virginia to individuals for military or other services. These lands were to remain subject to be disposed of oy the Comronwealth of Virginia until september 1, 1788 . After thes date all lands remeining within the limits of the district were to be supject to the disposition of Kentucky. The naviEation of the Chic River was to be free to the citizens of the United states. If a dispute were to arise between Kentucky and Vireinia conerning the meaning of the act, it should be settled by six commissioners.

It was further enacted that if the conventiou apm 
proved of Kentucky becoming a state on these terms, it should fix a day, prior to September 1, 2787, on winh the authority of Virginia vild cease. Wrereupon the "tirst Enabling Act" wovic "become a solemn corpact" between Kentucky and Virginia. However, before Tune 1, 1787, the Congress of the United states must assent to the erection of Kentucky into an independent state, must declare the authority of virginia over Kentucky endec, and must agree to admit the proposed state into the Federal Union soretime oetween the date to be fixed by Kentucky and September 1, 1787. The act said that to prevent the development of a perfod of anarchy, the Fourth Convention rust call another convention to meet sometime petwcer June I and September 1, 1787, to establish a fundamental constitution of covernment. 8

8.Iittell, op.cit., pp.72-76 
SFAPTER IV

INDIAN DANGERS 
CHAPTER IV

INDIAN DANGERS

Bu the terms of the Treaty of Paris following the War for American Independence, England was required to surrender the northwestern posts in her possessions south of the Great Lakes. However, fur-traders in Britain prevallec upon the government to retain these posts. The treaty also stipulated that no legal impedirents should prevent the collection by British merchants of the debts due them from citizens of the United States. Virginia, however, passed a law which prohibitec the collection of these British debts. Whereupon, Britain used this violation of treaty as an excuse for retaining the western posts. Congress, under the Articles of Confederation, was unable to control the sovereign states, and consequently the northwestern posts were heId unt1l Jay's Ireaty $(1794)^{2}$ had been ratified, moe than ten years ater the peace with Great Britain. The retention by Great Britain of these posts resulted in a continuation of the war in the

1. Hening, op.cit., Vol.2, p.76

2. Peter Porcupine, A Little Plain Enclish, Addressed to the People of the United States, on the Treaty Negoclated MIth His Britannic Najesty (Phjladelphia, Thomas Bradford, 1795) 
West while the wast enjoyed the fruits of the peace.

Early in 1784 nine comissioners were elected by Congress to treat with the Indians generally for the purpose of buyine land in the Viest. However, it was difficult to assemble representatives from a great number of tribes scattered over a vast territory. Afetr a time Congress realized the folly of attempting to rold this general treaty. Whereupon three commissioners were directed to trost with tribes north of the onio for lands there. The territory desired lay in the scutheastern part of onjo, about the mouth of the Muskingum River. It was claimed oy the Shawnees. Therefore earnest efforts were made to get them to attend the treaty meeting. It was held in 1785, but the shawnees refused to attend. Other tribes attended and granted to the United States a large part of the shawnee country, of which they did not own an acre. Notwithstanding Congress regarded tre Shawnee lands as duly ceded, ordered them surveyed, and provided for their sale. To et a better Indian title to the same lands, a treaty was finally drawn up with the Shawnees in January, 1786. The result was that the shawnees acknowledged the Uited States as owners of nearly the whole southeastern quarter of Ohio, promised to give up their white prisoners, 
to keep the peace, and, as security for the performance of their agreements, surrendered five of their leading men as hostages. 3 prey had no intention of keeping their promises, however. Twenty-three days later the hostages escaped, and soon afterward the Shawnees at large were joining the rost powerful comoination of north-western Indians since Pontiac's tirre, for the destruction of the whites on the ohio valley. It was known as the "Wabash Confederacy." Savage war had been oreeding ever since the Indians learned that Great $3 r 1 t-$ a in had assumed to transfer them and their lands to the United States and that congress was claiming the right to settle anc dispose of them. By 1785 sc many and destructive were the scattered Indian raids into Kentucky that the sugust convention of that year adopted resolutions calling upon the militia officers to "concert such plans as they may deem ex edjent... for carrying expeditions against the hostile nations of Inaisns. $" 14$

The particular expedition contemplated was against the Indians of the vabash confederacy; but as they lived out-

5.Bod $1 \in \mathrm{y}$, History of Kentucky, p.372 4.Iittell, op.cit., p.72 (Appendix No.V) 
sice of Virginia and in wat had pecome national territory no:th of the ohio, and as the government of virginia had expressly foroldden such expeditions, these resolutions seemed to defy the authority of poth the state and the United States. In 1786, however, Indian hostilities compelled the Kentucky people for self-preservation to carry such an expedition across the onjo.

Neanwhile Governor Patrick Henry was greatly concerned abcut Kentucky's danter. He wrote Congress complaining that it was a lowng its Indian subjocts to slaughter the Kentucky people without making any real effort to stop them and demanded to know: "Will congress defend and protect our Frontiers?"5 Rolizing that little could be expected from Congress, Governor Henry directed the field officers of the various counties in Kentucky to concert measures for their own defense, taking as their guide the Sixth Article of confederation. This Article reserved to each state the right to make war on the Indians provided "such state be actually invaded by enemies, or shall have received certain advice of a reso-

5. William W. Henry, Patrick Fenry, Vol.III, p.363 
lution being formed by some nation of Indians to invade such state, and the danger is so imminent as not to admit of a delay till the United States in Congress assembled can be consulted." 6

Before Governor Fenry sent the county lieutenants authority for an expedition, the militia officers had made considerable progress in organizine one composed entirely of volunteers. Clark had consented to command them; but, when, under the governor's authority, this expedition of volunteers was abandoned for ancther to be made up of drafted men, Clark refusec to command 1t. Under the militia law arafted men could not be lawfully carried out of the state without their consent. If taken across the ohio into the enemy's country, they were not compelied to obey orders. Some twenty-five hundred men were expected to gather at clarksville, opposite the Falls, wut so many had avoided the draft that only about twelve hundred appeared. Discord and sulking prevailed. Some fifteen hundred war-mad Indians, hovever, were known to be gathered on the Wabash, only about a hundred and fifty miles northwest of Clarksville; and for the army to disoand would invite de-

6. William Iittell, The Statute Law of Kentucky (Frankfort, 1810, Tohns on and Pleasants), Vol.II, p.II 
struction of homes and lives in Kentucky. Therefore Generyl Clark walvea his objections ano took command. He at once sent Colonel Iogan back to Kentucky to gather deserterd, draft alI the remaining militia, and attack the shawnees in chio, in order to draw off their warriors from the Vlabash. " Whereupon Clark proceeded to Vincen es. The march to Vincennes was scarcely underway when disorder became manifest among certain cfficers and troops. A delay of elght days at Vincennes increased their disaffection, for the supplies which were being brought by boat had been delayed on account of the low water in the Wabash. With assurances from clark that a further advance of a few days would bring them to the Wabash villages, the march was resumed. At the close of the third day two hundred troops mutinied, the report having been circulated that the supply of provisions would be exhausted before the Indian towns should be reached. 8

Whereupon Clark, arriving at Vincennes, established a garris on one hundred and fifty men. This force was thought to be sufficient to overawe the Indians, and it was hoped Kentucky would thus be free from further invasion.

7.Bodley, op.cit., pp.371-375

8.Tames A.T'Tmes, The Life of Ceorge Fogers clark (1928), p.355 
Clark then proceeded to pave the way for negotiations with the tribes on the Wabash by a message to their chiefs. He said that if hostilities were continued, "we shall...take posm session of jour Lands and make a conquest of them Forever without showing you any mercy." 9 This move was succussful, and hostilities were postponed. Thus in spite of desertions and almost total disorganization of clark's forces, the expedition against the Wabash tribes cannot be considered a total failure, since peace was restored for a period.

FUURTY CONVENIION, 1786: Notwithstanding, elections were held in August, 1786 , in the couties in accordance with the act of separation. Interest in the general movement for separation was intensified. Three conventions had been held and rore people had become informed on the separation question. Perhaps there was even a feeling of exasperation at the interminable delay that seemed to be pursuing the quest for statehood. In this movement General James Wilkinson first began to develop a popular leadership. ${ }^{10}$ He strove to ripen the public mind for an immediate declaration of ind pendence without going

9. Draper irSS, 11J108, quoted in Ibid, p.357 10. Connelley and Coulter, op.cit., p.237 
through the slow formalities of law. He was the first public 11

man to make such a statement. Nevertheless a few of the members convenea at Danville on the day appointed in the Virginia Act, but so many of the members hed marched with clark and Logan, that a number sufficient to proceed to business could not be had. However, on september 26, the rembers present formed themselves into a committee and prepared a memorial to the legislature of Virginia, relating the reason that the convention could nct proceed to business. The memorial requested that some alterations be made in the act of separation, and, after appointing John Marshall, afterwards to become the great chief justice, to present the memorial to the virginia legislature in Fichmond, the committee dissolved itself. In order to prevent the cessation of the powers delegated to the convention, and the consequent delay of separation, some members with Thomas Todd, the clerk, attended regularly and adjourned from day to day until sometime in January, 1787. It was not until that time that a quorum was obtained and business proceeded with. It was immediately voted, in the terms of the Act of Separation passed by Virginia, "That it was expedient for, and the will of the good people of the Iistrict to

11. Collins, History of Kontucky, Vol.I.,p.262 
separate from the blate of Virginia, and become an independent state." 12

The proceedings of the Fourth Convention were interrupted by a letter which the president of the convention, samuel MoDowell, received from a memoer of the Virginia Legislature. This letter bore news of the repeal of the law under which the convention was then acting, and the calling of another convention to be held at the same place in september, 1787. The reasons assigned for this measure were: "That the tire contemplated in the repealed act was not sufficient to enawle congress to determine on proper deliberation as to the propriety of admitting the proposed state into the Union; That twelve months had been given for purposes which could not now be complied with in that ime; That the people of the district were represented as beine much divided respecting the propriety of a separation." ${ }^{16}$ These divisions can be ascribed to James Wilkinson and the results of Clark's Wabash expedition. Wilkinson's radical procecure, his efforts to ripen the public mind for an immediate declaration of independence, without going through the slcw formalities of law, provoked party divis-

12. Littell, op.cit., p.16

13. Ioid. p.17 
ions - some agreed with him while others alffered in various degrees. "Wilkjuson was active and heated in the promulgation of his views. He announced himself a candidate for the convention, and it was given cut in speeches made by wilkinson himself, that he would, on the first day of tre election, at Iexingtion, address the people, in order to persuade them to an immediate separation, without regard to the conditions imposed oy the act of the assembly. Many were alarmed...; many who vere in favor of separation itself, $y \in t$ deemed the evils that might be for a time continued by avajting the time designated, and pursuing the course pojnted out by the general assembly, far less to be dreaded than the consequences of this revolutionary course which wilkinson urged."14 Humphrey Narshall answered wikjnson in debate. The tro arpead on the propriety and the necessity of a separation. The time when this should take place, and whether fndependence and sovereignty shoula be assumed as an inherent right (willinson) or be regulated oy the law of the parent state (Marshall), berame the partiolar subjects of controversy.

14. T.M.Green, op.c1t., p.63 
In a letter to Colonel Thoras Viarshall, John Inarshall said that "the ant is not precisely sunh as I wished it to be, nor is it, conformable to the resolutions of the committee before whom I appeared." 16 frorshall said that those who passed the law reasoned that the power delegated to the Fourth Convention oy the poople of Kentucky, to decide upon a separation from virginia, was limited in point of time to a decision to be made in such time that Congress might determine on the admission of Kentucky into the Union oy June 1, 1787. John harshall said "that you are very mon divided anone yourselves, [attrioutable to the hilkinson activities] 15 and there does not appear to be in the minority a disposition to submit it with temper to the decision of the majority, and (sjince) the measures of the convention, in conscquence of a defect in the orfiginal law, wuld be liable to some objection, the rost safe...plan is, to pass a law, In which the defects of the former act may be corrected, and which sball...call... a new convention... the decisions of which the disappointed can make no oojection." 16

Up to the Fourth Convention, the proceedings of the

15. Writer's prackets

16. Litte11, op.c1t., (Appondix No.7), p.76 
separation question had been moderate and patient. But this most recent action of the Virginia Legislature, the passage of the second Enabling Act, was not warmly roccived. The Kentuchians found themselves no further advanced than they had been a year before in their efforts to separate from virginia. Noreover, the inconveniences whin had precipitated the separation moverent continued to berome more serious. Thrs the members of the Ficurth convention returned home in an unsatisfied attitude of mind.

PLE ISSISSIPPI QUESTION: DUring Varch, 1787, word was received in Kentucky that Tohn Jay, the Confederation Secretary for Forelgn Affairs, had made a proposition to Don Cardoqui, the Spanish Minister in New York, to cede the navigation of the Mississippl kiver to Spain for twenty-five or thirty years, in exchange for some comrercial advantages to be granted to the United States, but from which the people of the western country culd never derive any benefit. It was evident to the already aroused Kentuckians that this measure intended to sacrifice the interests of the west to promote the prosperity of the last. This information was issued in a comrunication from a correspondence committee in the western part of Penn- 
sylvania to the people of Kentucky. Tohn Marshall in his letter to Thomas harshall also mentions this new development in the East: "The negociation which has been opened with Spain, for ceding the navigation of the lississippi - a negociation so dishonourable and injurious to America, so destructive of the natural rights of the western world, is warmly opposed by this ccuntry, and for this purpose the most pointed instructions are given to our delegates in Congress."17

As Bodley says: "When to 2.1 other causes of complaint on the part of the Kentuckians (their dire poverty; the desperate savage war they had endured for years after peace had come to their fellow-Americans east of the Alleghanies; the indffference to their danger on the part of their state and federal governments; and the closing of their only market outlet by the Spaniards) was added this... attempt of the northern major1ty in Congress to barter away their navigation right, who can wonder that the Kentuckians were wrathful; or that they demanded a prompt separation from Virginia and a state government of their own to look aftor their own interests; or if manj of them hotly dencunced Congress; or if some talked of revolt from the

17. Ibid. (Apendix VIII) p.79 
Confederation, and others feared that continued injustice might bring it about."18 Secession from the Union was hardly loss demanded in New England, if the commercial treaty were defeated.

This information was recelved at Danville during the session of the Supreme Court for the District, where a considerable number of people were attending. The matter was taken into immediate consideration, and a committee was appointed to communicate the information to the people at large. This communication took the form of a circular letter airected to the different courts in the western country. This circular letter was dated Warch 29, 1787, and was signed by Ceorge Muter, Hariry Innes, John Brown, and Benjamin Sebastian. It requested the inhabitants of the various counties in tho District to elect five memoers in each county, to meet at Danville, in May, 1787, to consider the move of congress, to prepare a remonstrance against the cession, and to take every step necessary to preserve the happiness of the West. 19 several of the -lected members met at Lanville in May, but, after conferring several days, adjcurned without adopting any measures respect-

18. Bodley's Introduction to Littell's op.cit., p.xv

19. Ioid., p.78 
ing the matter. The reason was that they learned that the Virginia Legislature had passed resolutions on the supfect and had instructed their delegates in congress to oppose the cession. If the other scuthern states took the same stand as virginia, no such treaty could be ratified, because nine states were required for such action.

The resolutions passed $b$, the Vir inia House of Delegates, November, 1787, vojced the sentiments of the scuth and West concerning the navigation of the Mississippi. These resolutions read thus:

\footnotetext{
"Resolved unanimusly, That the free use and navigation of the western streams and rivers of this commonwealth, and of the waters leading into the sea, do of right appertain to the citizens thereof, and ought to be considered as guaranteed to them by the laws of God and nature, as well as compact. "Kesclved unanimusly, That every attempt In congress, or $\in$ lsewhere, to parter away such right, ught to be considered as subversive of justice, eood faith, and the great foundations of moral rectitude, and particularly of the principles which gave birth to the late revolution, as well as strongly repugnant to all confidence in the feceral government, and destructive to its peace, safety, happiness, and duration.

"Resolved, That a committee ought to
} 


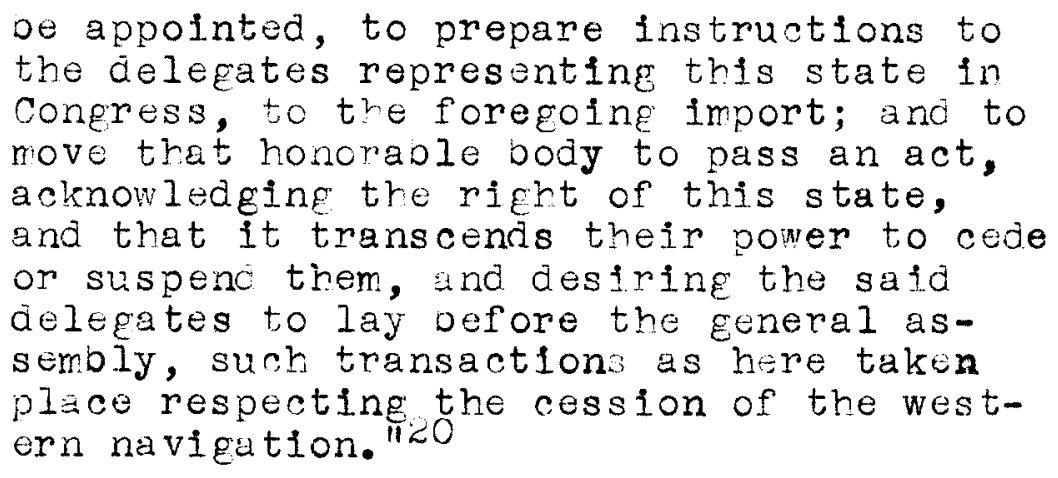

The people of Kentucky were reassured by this action, but events of 1787 showed anew the necessity of separation on the part of Virginia, and they awaited the August, 1787, elections with the expectation that they would finally enter the confeceration as an independent state.

Clark's desperate strugele to hold vincennes and the Illinois orought rebuke from virginia. The evil days for Ceorge Rogers Clark began when Edmund Randolph replaced Patrick Henry as Governor of Vireinia (December, 1786).

"It appeared from letters received from Thomas Narshal1, oy the Exucutive of Vireinia, dated at Lanville, Kentucky,

20. The Xentucky Gazette (Reproduced by the photostat process), VoI. I, Saturday, Tanuary 26, 1788 
that General George Rogers Clark had undertaken, without authority, to raise recruits, nominate officers, and impress provisions in the Distrint of Kentucky, for the defense of the Post at Vincennes, and had for this purpose, also seized the property of spanish supjects, contrary to the laws of nations. Clark was at once notified that his conduct was not only disavowed oy the Government of Vireinia, but that their displeasure was incurred. thereby, and that the Attornoy General of Kentucky had been instructed to take steps to bring to punishment the of fenders."2I

Thus Governor Randolph wrote to Harry Innes, Attorney-General for the Iistrict of Kentucky: "We have reason to believe that the late hostilities, committed on the Indians, have roused their resentment. It is the duty of government to prevent and punish, if possiole, all unjust violences. I beg leave, therefore, to urge you to institute the proper legal inquiries for vindicating the infractions of peace."122 Innes answered Governor kandolph's letter, saying: "__ how am I to proceed on this business from so vave a direction, I know not. In my official capacity I cannot do it, in a private capacity it

21. Calendar of Virginia state Papers, Vol.IV, p.322 note TTo a letter from Harry Innes to idmund Rancolph, dated July 21, 1787, the editor of the above work, wiliam $P$. Palmer, N.D., affixed this noted

22. Littel1, op.cit., (Appendix No.X, Nay 1, 1787), p.80 
would render me odious. "it Innes told how the Indians were constantly menacing the safety of the Kentuckians, and that various expeditions were fitted out to head off these attacks. Innes intimated that he cculd not convict a people who were trying to protect themselves. He concluded his letter thus: "The Indians have been very trouolesome on ou frontiers, and still continue to molest us, from which circumstance I am decidedly of opinion that this western oountry will in a few years act for themselves and erect an independent government; for under the present system we cannot exert our strength, neither does congress seem disposed to protect us, for we are informed that those very troops which Congress directed the several states to raise for the dufense of the western country, are dispanded. 23 I have just dropped this hint to your excellency for matter of reflection. If some step is not taken for our protection a litile time will prove the truth of the opinion." 24 Thus no action was taken.

23. Kepeated efforts were made by General Henry Lee of Virginia to ootain a continental force of 700 , or even 800 men, to protect the western frontier, out the states feared the growth of power in the central government that might result from such an action, and consequently Lee's efforts failed.

24. Littell, op.cit., (Appendix No. X), pp.81,82 
Humphrey Narshall uses this letter to convict Innes of plotting with wilkinson to bring about Kentucky's secession from the Unfon. However when this letter was written, Wilkinson was in New orleans. As Temple Bodley say , Governor Randolph was the last man to hom Innes wculd have been likely to write a letter disclos ing treasonable designs.

"The warning given the governor of the danger of revolt seems persuasive evidence that Innes hoped thereby to bestir virginia and congress to prevent such a revolt... Virginia having twice expressec her wilingness, and the need being plain - Kent cky was morally, if not technically, justified in setting up an independent state governm ment without waiting for the assent of a hostile northern majority in congress. They argued that Kentucky would be more likely to we promptly adritted into the Union if it had a separate covernment than if it applied for admission while part of Virginia; that with a vote in songress like any other state, it coula secure protection of its richts。" 25

THE KENIUCKY CAZETTE: On Aucust 11, 1787, there appeared in lexington a force wroh was destined to play an important

25. Temple Bodley in Introduction to Littell's Political Trans-

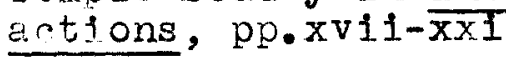


part in the future discussions of the District. This was the printine press with its product, the Kentucke razette, 26 ecited oy Tohn and Fielding Bradford. Efforts of the second convention to have a newspaper started were thus rewarded two yoars later, in time for it to play a part in shaping affairs for the fifth convention. The people took advantage of this opportumity to voice their views on current questions, and neturally the question of separation came in for much discussion. In the second Issue appeared a long poem, a paraphrase of Famlet's Soliloquy, beginning, "To sever or not to sever, that is the question-mbether itis nobler, in the mind to suffer the stings and arrows of keen disappointrent, The gibes of politicians and of wits; or to retire from all the $\mathrm{s} 1 \mathrm{l}$ y contest wrich reep ambitious mortals in a ferment, etc."27 This wes followed in the next issue by observations on poth sides of the question. "A Farmer" said that: "As the rost of us are farmers and unskillec in policy (althol we are anxious to do for the best) we are able to give but a random guess at the propriety of a separation---ve an see difficulties on ooth sides and would wish to avosd the worst." He said ho

2E. With the exception of the Pittsbure Gazette, it was the first newspaper puolished west of the Allegheny rountains 27. The Kentucky Gazette, August 25, 1787 
would like to propose queries to the gentlemen on both sides of the question. He began by asktng those who believed separation to be necessary:

"By what provable means can a new state support Government, defend itself from the savages, snd pay its quota of the federal and state debt without a free trade of the river Mississippi?

"What provable prospects can a new state have of ootainine a trade down the rississippi; and what profits can we derive from such a trade?

"Will not a separation lessen our importance in the op nion of the savages, and cause them to fall on us with greater vigour?

"What are the great evils we suffer from want of a new government; and row cculd a new state remedy those evils?"

To the opposition he put the following questions:

"How shall we defend ourselves against the savages under the present laws; and how shall we get paid for doing it?

"How can we pay the taxes now laid on land, tithes, horses, cattle, alienations, process, ctc.?

"How can we take any steps towaras promot,Ing and regulating $\varepsilon$ profitable trade down and up the rivers? And will tre Assembly regulate such trade to our advantage?

"Is it not our true interest to become a ranufacturing people now in our infancy; and. what power have we to encourage Arts and Vanufactures, and encourage luxury, without a new Eovernment?

"How can we encourage learning and science 
in our present situlion; and will not the next aneration suffer ereatiy for want of it?

"Woulc not a government within the district have a tendency to correct the practices of the jisorderly and licentious; and restrain the abuses of power practiced of late by some of those in authority?" 28

This farmer obviously favored separation yet was willing to hear both sides discussed. He raised some very pertinent questions which were given considcration in subsequent conventions.

Ten days before the fifth nonvention met, an article appeared in the Kentucke Gazette strongly ur ing opposition to the erention of a new state. The argument came from "An Inhabitant of Kentucky" that

"in case of a separation we shoulc have a greater burden of taxes then if we remained united. Cur proportion of the national debt being fixed on us, in addition to the charges of a separate government, would make our tax greater than if we were only called on to pay the same debt, and a proportion of the charges for the Government of Virginia. Iet us not be deceived with what is said as to the small number of officers that would be wanting and the srall salaries they would require. Amoition would always carve out of-

28. The Kentucke Gazette, August 18, 1787 
fices, and avarice would require large salam
ries?"zQ

In this Fourth Kentucky Convention the separation question, for the first time, berame national and even international in the scope of 1ts importanco. The problem of the west is brought to the attention of ooth the virginia and the United States governments. The Fourth Convention met to consider the terms Virginia offerec for separation. This was the first convention whinh was unable to muster a quorum and meet on the day pecified. When it finally met its proceedings were sharply interrupted with the news that it was not a legal convention. The subsequent developments following the failure of the Fourth convention are important in und rstanding the problems surrounding Kentucky's efforts to become a sta te.

THE FIFIH CONVENTION: Elections were held in August, 1787, in preparation for the fiftr convention. The attitude of the voters and memoers was apparently affacted by the recurrence of the Indian danger and the fallure of either Congress or

29. The Kentuck Gazette, September 8, 1787 
Virginia to afford protection.

As a consequence of increasing Indian hostilities in the north, the canty lieutenants of Iincoln, Fayette and Jefferson met on hey 17, 1787, and sent a memorial to Vireinja. On June 5, 1787 , the Virginia Legislature reported to Kentucky that the letters and papers received from the county ljeutenants would be forwardec to Congress. Colonel Benjamin Lo an was directed to immediately convene the commanding officers of the ccuties in the district and work out some system for defense; but, continued the comminication, "cautiously avoioing offensive operations, and taking care that the troops which it may be necessary to embody, for carrying into execution any plan of defense that may be adopted, do on no occasion go without the limits of the state, except in the immediate pursuit of an invading enemy. " 30

As early as 1780 the Kentuckjans had learned that the only way to prevent an invasion from the Indians, was to

30. Iittell, op.cit.,pp.82, 83 (Appendix No.XI) 
plan an offensive move against them; otherwise the Kentuckians would be at the mercy of the invading enemy. This "sj.tand-wait" policy had not proved successful in the past.

on July 21, 1787, Virginia received an answer from Congress concerning the defense of the district. The answer was rade in the form of two resolutions. The first resolution declared that the troops of the U.S. would be placed in such positions "as shall afford the most effective protection to the frontier inhabitants of Pennsylvania and Virginia from the incursions of the Incians." 31 All the troops except those at the falls of the Ohio were stationed at such a distance from the settled parts of rentucky as to be of no service to the people. The second resolution requested the exeeutive of Virkinia to order the militia of the distrint of sentucky to hold themselves in readiness to unite with the federal troops in such operations as the officer commanding them may deem necessary for the protection of the frontiers, jut the governor of Virginia added that Kentucky would have to

31. Ioid. (Appendix No.XII) p.83 
have virginials permission to fulfil this act. 32 This clause attached by Virginia spoiled any possible benefit Kentucky might have received from the congressional resolutions.

The Fifth Convention met on september 17, 1787, and proceeded to ousiness. The sessions of this convention were not marked by exciterent or debate. It was unaimously resolved that Kentucky be erected into a separate and independent stato on the terms specified in the two acts of the Virgiria Assemoly. The legislature of Virginia was requested to use its influence to have an inhabitant of the district chosen as one of her delegates in the Congress. This request was granted and John Brown ( a member of the Virginia Legislature as senator from the counties of Kentucky) became a memoer of the virginia delegation in the Con inental Congress, specifically representing the District of Kentucky. (He was later the first senator from the state of Kentucky serving three consecutive terms.)

The Fifth convention adaressed itself to the United

32. Ioid. (Appendix No.XII) p.84 
States congress. It said that the desire to separate foom Virginia "dows not proceed from any impatience under the necessary restraints of her government, which we think wisely organized and well adrinistered; but our remote situation fror the seat of that government, and the many interjacent natural impediments, prevent our enjoying equal advantages with our eastern brethern, and preclude the idea of a connection on republican principles." 33 The communication asked that congress ratify the compact between Virginia and Kentucky, and arrange to receive Kentucky into the union as a state. Congress was requested to act quickly in this matter because the Virginia Act granting Kentucky's separate statehood made the grant conditional on the assent being given before July 4, 1788. Also the states were then voting on the adopticn of the new Federal Constitution, and if it were adopted by nine of them, the continental congress would nease to exist.

This convention requested that a convention be elect33. IbId. (Appendix N.XII) p.86 
ed to draw up a constitution. It recommended that in the folIowine April, on the respective court days of the counties, five representatives from each of the seven counties, should be elected $b_{d}$ the free male inhabitants to continie in convention ustil December 31, 1788. In order that full opportunity right De given for exerrising the right of suffrage, each of the officers in charge of the elections were instructed to keep the polls open for five days, and were to frequently read the resolutions from the court-huse door. Tohn Bradford was asked to prblish the resolutions in the Kentucki Gazette six weeks successively, irmediately preceding the time of holding the elections.

TONCRESS DELAYS AND POSTPONES: The Kentuckians felt that by having a delegate in Congress, their appeals might be more carefully considered. Therefore Tohn Brown was elected. In New lork, where congress was in session, Brown loved with James lladis on. Years later ladison said of jrown: "I owe it to Nr. Brown, wh whom I was in intimate friendship when we were assoclates in puolic life, to observe that I el ways regarded him, whilst steadily attentive to the interests of his constituents, as duly impressed with the importance of the 
Union, and anxious for its prosperity."34 Indeed, Madison depended mainly on Brown to secure Kentucky votes in the virEinia convention for adoption of the Fedral constitution; the adoption hung upon Virginia's action, and trat in turn, upon the votes of the entucky delegates. 35

The special mission of Tohn Brown, as the only Coneressman from Kentucky was to get the earliest possiole assent of congress to Kentucky's prompt admission into the Confederation. When congress convened, 3rown irrediately appeared to present the ifth convention's petition for admission into the Union. But the old Confederation government in all j.ts parts had by this time fallen so completely into disrepute, that for months no quorum conld be ootained. Brown presented his resolution on Eebrary $29,1788,36$ but not until Nay $\leqslant 0$, did congress take any defunite action. Un March 4, 1788, Congress was resolved into a comrittee of the

34. Ietters and other tritines of Tames radison, op.oit.,

35. Bodley's Introduction to Ijttell, op.cit., p.yxi1

30. Tournals of tho gontinontal congress, Vol.XNXIV, .72 
whole. lin. Otis, who was elected to the nhan, reported that the comritiee had considered the Rentucky guestion, but had not como to a resolution, anc desirea to have more tive. This request was granted. On Nay 30, 1788, Congress aga in assemoled. "According to an order of the day congress was resolved into a nomittee of the whole on the potition in behalf of the inhaitants of the distr ict of rentucky, and a motion made thereon."i7 After some time the chairman (ir. otis again) reported that the comrittee considered the subject referred to them, ut did not have tire to act on it, and they desired leave to sit again. It was resolved that concress on the following wondsy resolve itself into a committee of the whole to proceed on thrs business. On June 2 , 1788, Mr. otis reported that the comptive had agreed "that in their opinion it is expedient that the district of Kentucky be erected into an independent state."38 They recommended that the question be referred to a committee consisting of a member from each state, to prepare and report an act for acceling to the independence of the district of Kentucky, and for receiving it into the Jnion as a member there-

37. Iold. p.189

38. Ioid. 0.194 
of, in a mode conformale to the Articles of Confeceration. The next day the report was accepted, and the committee was elected, composed of eleven members. 39 on July z, 1788 , Tohn Brown made a motion for tho purpose of ratifying and confirming the corpact between Vircinja and the olstrint. Consideration of this motion became the order of the follow Ing aay. 40 It read:

"Whereas it appears to Congress that the state of vireiria by two acts of the legislature thereof, (October 1785 and october 1786) hath entered into a solemn compact ith... the district of Tentucky permitting the same to be erected into a separate and independent state to be admitted into Urion ith the United states as a federal memoer thereof upon certain torms and conditions in the said acts stipulated ano it further appearing to Congress that the said aistrict in convention assembled did in conformity to the said acts by certain resolutions cntered into September 22, 1787, autermine that it was expedient that the said district should be erected into an independent state on the terms a d conditions specified in said acts and did present to congress an address praying to be admitted into union with the U.ited States as a federal memoer ano thereas it appears to Congres to be just and reasonabde that the application of the said district of Ken-

39. Ioid. p. 198

40. Ibid. p.287 


\begin{abstract}
tucky shoula be complied with:
"Resolved therefore that the Uajted

States in Congress Assembled do ratify

and confirm the compact entered into be-

tween the state of Virginia and the dis-

trict of Kentucky... and that the said dis-

trict be admitted into union with the

United States as an independent federal

member on Tanuary 1,1789, and be stiled

the Commonwealth of Kentucky. 4 I

"Resolved that Concress will release

the state of Virginia from all federal

obligations arising within the said district

after January 1, 1789 , and from such

part of $h \in r$ quota of the continental debt

as shall be apportioned to the said ais-

trict whenever the same shall have been

ascertained agreeably to the stipulations

of the compact aforesaid.

"Resolved that the said district shall

be admitted to a representation in congress

after January 1,1789 , provided from an ac-

curate census it shail appear that the

said district contains 60,000 inhabitants." 42
\end{abstract}

The Northwest ordinance of 1787 said that states

41. (That is the body of polo constituting a state or a olitically organized community. rassachusetts, Pennsylvania, Vireinia, and Kentucky are officlally callec comronwealths. The words state and comronwealth are used interchangeably in referring to Kentucky. The State of virginia, in referring to Kentucky used the term "Cpmmonwealth." The Federal government used the term "State.")

$42 \cdot$ Ibid. pp. 287,288 
were to be admitted "whenever any of the said States shall have sixty thousand free inhabitants therein," and they were to come into the sisterhood "on an equal footing with the original states in aII respects whatever." 43 The population requirement for statehood followed in the northwest may have influenced Brown. There is no evidence, however, that it did.

A motion was then made $b_{j}$ Mr. Nathan Dane, llassachusetts, to postpone $\mathrm{Nr}$. Brown's motion. Temple Bodley attributes the delay in the Continental Congress to the hesitam tion on the part of the northern states to admit another southern state into the Union which would destroy their majori ty vote in Congress. ${ }^{44}$ However, the reasons given by Congress were:

"that hine states had adopted the con-
stitution of the United States ; and
whereas a new confederacy is formed among
the ratifying states, and that Virginia
has become a member. And whereas an
Act of congress in the present state of the
government. severing a part of the said.
state from the other parts... may be attended

43. Ordinance of 1787, Article 5

44. Bodley's Introduction to littell, op.cit., p.xxiv 


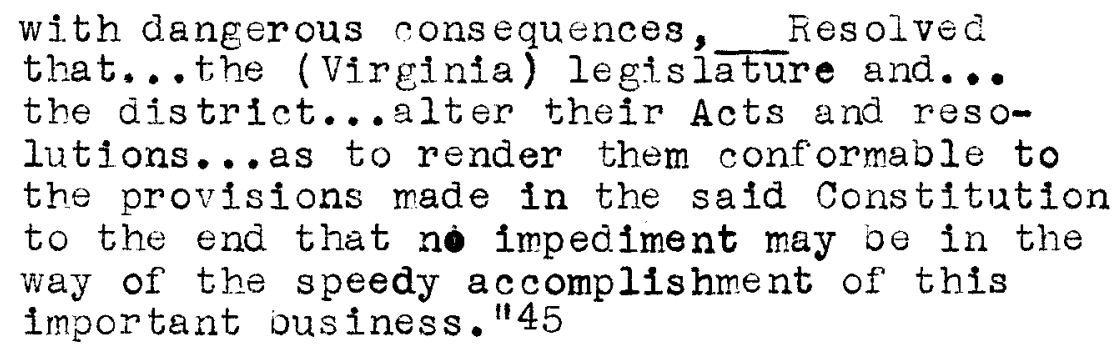

This motion was passed July 3, 1788.

Thus Kentucky was again disappojnted, even after having twice gone through all the formalities required by Virginia. She had no hope of better treatment from the new government. Westernors generally were suspicious of the effects of the Constitution.

45. Journals of the Continental Congress, Vol.XXXIV, pp.289,:290 
OEAPTAR V

ADMISSTON AT LAST 
GHAPTER V

ADNISSION AT IAST

THE SPANTSH CONSPIRACY: Throughout his mission to the United States as ambassador from Spain, Diego de Gardoqui's main concern at New York was to establish personal relations with the members of Congress, and to set North and South, and East and West aganst each other. Cardoqui flattered himself, and assueed his government that he had in a large measure formed. and maintained a pronounced Spanish opinion in the Atlantic States and among the New England delegates adverse to the Interests of the ivest, $I$ and favorable to a stoppage of the river navigation. $Z$ The element of secrecy was absent from all these conferences. The delegates communcated and discussed them freely amone themselves, and published them oy their correspondence. 3 To secure Spain's possessions from invasion, Cardoqui's aim was to prevent the growth of American

1. Gardoqu1 to Floridablanca, August 6 , 1786, in Brown, op.c1t., p. $1 \overline{36}$

2. Gardoqui to Floridablanca, Secret Dispatch No.6, November 21, I785, in Ibid. p.136

3. Io1d. p.138 
power, by fostering sectional quarrels which might break up the Confederation. The chief means he used was the treaty proposed to Tohn Jay. The idea of commerce with Spain's dominions wes attractive to the North; the proposed closing of the Vississippi was unattractive to the South and west. The northeastern states feared that the admission of Kentucky woula destroy their majority in congress. 4 Tohn Brown was approached by Garoqui with an offer to open the Mississippi to Kentucky - but he said that this privilege could never be extended to them while part of the United States, by reason of commercial treaties existing between that court and other powers of lurope. 5

3rown had fawored entucisy organizing a state covernment ithout virginia's consent, ${ }^{6}$ since it was so aifficult to get Virginia, Kentucky, and Congress to agree upon identical terms. Then, too, with Kentucky judependent of Virginia

4. Booley's Introduction to Iittell, op.cit.,p.xxiv; 300ley, op.cit., $\bar{p} \cdot 433$

5. Gardoqui to Floridablance, Tuly 25, 1788, in T.M.Gran, op.cit.,op.100,16I; Brown, op.c1t., pp.146-148

6. Connelley and Coulter, op.c1t., p.258; Green, op.c1t.,p.155 
Congress would hardy have dared refuse its admission; for that may have resulted in an alliance with Great Britain or Spain. when Congress kept putting off Brown's motion for Kenturky's admission, and finally refused it, he attributed this defeat to the jealousy of the northern states. ${ }^{7}$ He sajd the eastern states would not assent to the admission of Kentunky unless Vermont or the province of laine were orought forward at the same time.8

Brown comminicated Gamagui's overture confidentially; for public knowled of it in rentucky, coming after the news of Congress' refusal of "entucky's admission, might have resultec: in a demand for secession and acceptance of Spain's offer to open the Mississippi. 9 The suggestion in letters to George Inter sno samul McDowell tret this information be troated as confidentiel. jndicated that Brown wishec to avoid arousing a secession spirit in Kemtucky. After havine discussed Gardoquils project with Tares radison, Brown deemed it inexpedient

7. Bodley's Introouction to Iittell, op.cit., p.xxxv

8. Tohn Brown to Gorge Iuter, Tuly 10, 1788, quotod in Tbid, pp. yyxi-xxxiti

S. Ioid, p.xxxvi 
to make any further communcation on the suoject. Afterwards, in reply to an inquiry from a Kentucky historian, Madison wrote "that a knowledge of it in Kentucky, might, in the excitement there, be mischievously employed."10

During the ferment in the west, following Tay's proposed treaty, demes Wjlkinson saw an opportunity for personal profit. He planned to make a river trip down the Mississippi to New orleans with a boat load of Kentucky products, deceive Estevan Niro, the Spanish Governor of Lonjsiana, and attempt to convert bim to his plan. Wilkinson planned to offer the Spanish Kine his influence in Kentuoky to dotach it from the United states, and rake it a friendly ouffer state to protect Iouisiana from the Northwest. 11 In parsuance of this plan, Wilkinson fitted out a fleet of boats. Before leaving, he instructec a confidential agent to warn Governon iviro that the arrest of so eminent an Amerinan as himself would result in war and Spain's loss of Louisiana. The result was that lil-

10. Tamos Madiso $n$ to Man $n$ Butler, october 11, 1834, in IbIa. ppXXXV

1. Bocley, Fistory of Kentucky, 0.378 
kinson vias not arrested; instead Miro gave him an attentive 12 rearing.

Wilkinson explained to Miro the restlessness of the Kentuckians under the neglect of Congress and Virginia, their need of the navigation of the ississippi, and their intention to win it by invadine Louisiana and driving out the Spaniards. Fe saic that an army was being mobilized for this purpose at Vincennes. Wilkinson said his Influence in Kentucky was ereat enough that with liro's cooperation he could prevent this invasion, and to do so he was willing to expatriate himself and take an oath of allegiance to spain. To satisfy Mro of his ability to accomplish what he proposed, wilkinson shower that he had become the dominant military leader of the west supplanting Clark. Before leaving for New Orleans, he concocted. apparent proofs to discrecit his rival. This he did by making up forged papers and taking them and others apparently vouching for him to Miro. ${ }^{\text {su }}$ Niro immediately fell in with wilkinson's scheme. Wilkins on seid that in order to tempt Kentucky to secede from the Union and make a friendly treaty with Spain,

12. Bodley's Introduction to littell's, op.cit., pp.xxxix-xi 13. Booley, oo.cit., p.379 
he must be goven an exclusive privilege of trading with New crleans in Kentucky products. The propable motives of wilkinson have been thus interpreted: "...to dangle before viro the promise of Kentucky's secession from the United States and dependence on Spain, while he dangled before the Kentuckians the promise of an open market for their products at liew Orleans; but all the time he would put off performance of voth promises while his purse fattened on the profits he could malse by buying the procuets of the Kentuckians on his own terms and selligg them in New orleans for several hundred percent advance."14

The government of Spain was especially pleased With wilkinson's scheme; they foresaw that, if only Kentuckians used the lower Mississippi, the lands of Congress north of the ohio, being denied any trade outlet, would oecome stagrant; emigration from the Fast woulc avold those lands and go to Spain's ally, Kentucky; the Confederation, thus rendered unable to sell the public lands, upon which it relied for

14. Bodley's in Littell, op.cit., pp.xl,xl1 
financial restoration, woulo fall. 15

Wilkinson wanted political disorder in the west - not efficient feacral or state government. If he were to profit by his trade privilege, the controversy in congress over the navigation must continue; the Kentuckians must be kept wronght up about its proposed surrender; to Niro they must be made to seem almost ready for secession from the Union.

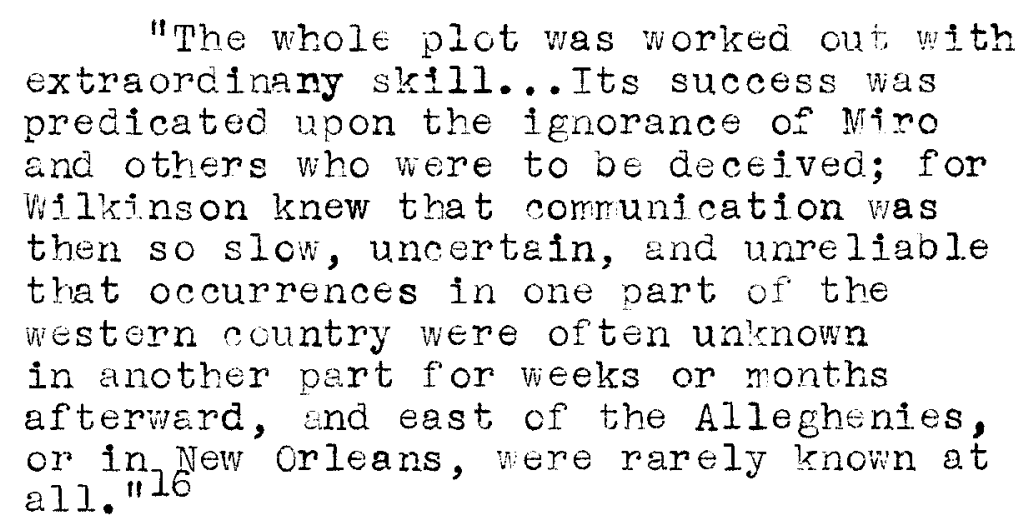

With these schenes in mind, wilkinson became a member of the Sixth Convention of July 28, 2788.

THE PCITICAL CLUB: During the time the Kentuckians were

15. Ioid. p.XII

16. Bodley, op.c1t.,p.379 
preparing for thetr sixth convention, an organization called the Danville Political Club, which was org nized in December, 1786, was playine import nt part in formulating ideas into constitutional provisions. This club was so closely identified in its merbership with the Fifth and successive conventions, that it can almost be called a secret caucus of those assemolies. This organizetion beame a training schocl for the future statesmen of Kentucky. Its membership was very exclusive. This club discussec alj problems concerning the welfare of Kentucky and the Unjted States, onstitutional and otherwise. The Danville Political club and the Kentucky Gazette thus kept the Kentuckians informed on the moves o their conventions.

\footnotetext{
"The seriousness and business-like cravity of the olub, and the practical character of the whole movement are seen in the first questions taken up for onsideration. The, were the allabsorbing topics of the day. At no time in the subsequent history of entucky have the people been more profoundly stirred than they were by the questions of 1786. There was ureent need for calm and dispassionate interchange of thought amone the recognized leaders of the people. The benefit of the cluo in affording opportunity for consultation among these leaders can not be over-estimated. The conclusions reached...disclose intelligent thinking ana sound judgement. The first question discussed by the club was... Whether the immediate navi-
} 
gation of the Mississippi River will contribute to the interests of this District or not?'...the club decided this question in the negative... The minutes do not disclose any reasons or arguments."17

In this year, 1788, the Kentucky frontiers were infested by the Indians; and while "its inoffensive cltizens were oleeding under the tomahawk and scalping knife, murdered on the road to the interior counties, and butchered on their farms and in their houses, and cculd obtain no protection from their eovernment; Congress, on the first cay of september, resolved to Eive protection to the Cherokee Indans, 18 the notorious roobers and murderers of the people of Kentucky." 10 This measure made the Kentuckians more determined than ever to obtain a separation and thus the privilege of protecting themselves.

THE SIXTH CONVENTION: During the time that the business of the Fifth Convention was before Congress, the inhabitants of Kentucky felt sure that their appeals to Congress, oy their

17. Thomas Speed, The Political Club, Lanville, Kentucky, 17861790 (1894), pp.107, 108

18. Ijttell, op.oit., p.95

19. Ibia. p. 29 
representative, Torn Brown, would meet with success. They had been notified that the committee of the whole had decided in favor of separation, and that a comrittee had been appointed to draw up an act for admission into the Union. The Kentuckians regarded these steps as positive proof of the success of their efforts, and viowed all that was to come as mere formality. Elections were held in April, 1788, for a convention to form a constitution. The elected memoers assembled at the courthouse in Danville。 $2^{O}$

A quorum was not present until Tuesday, Tuly 29. Nr. Thomas Todd was made clerk, and the Honorable Samuel McDowell was unanimously elected president. A Cormittee of Privileges and Elections was appointeo to examine the Certificates of Elections from the different counties. Papers addressed to Samuel NoDowell were read and it was discovered that Congress had postponed the admissi on of Kentucky . On Wednesday, July 30, a resolution was introduced declaring that the powers of this convention, so far as depends on the Acts of the Legislature of Virginia, were annulled oy the resolutions of congress. Another proposed resolution said, however, that it was the

20. (The Filson Club has photostatic reproductions of Thomas Todd's minutes of the Sixth, Seventh, Eighth, Ninth, and Tenth Conventions. These mintes do not include the debates. This volume is entitled: Journals of Conventions at Lanville, Ky., 1788-1792 (Unpurijsheo at present) 
duty of the Convention, as represcntatives of the people, to frame a const tution of goverrment for the district. Both rosolutions were submjtted to a committee of the whole convention. The result was a victory for the conservatives. The comittee reported that since the present convention had no legal power, and since it was essential that the people of the district were interested in their own welfare, it recommended that each county "elect five ropresentatives on the time of holdine their courts in the month of october next to meet at Danville on the first ionday in November following to continue in office until the first day of Jamary, 1790. And that they delegate to their said representatives full powors to take such measures for obtaining aomission of the District as a separate and independent member of the United States of America, and the navigation of the River Mississippi as may appear most conducive to these inportant purposes; and also to form a constitution of Government for the Listrict." ${ }^{21}$ The elections were to last five days. The sheriffs were to hold the elections ano make returns to the clerk of the Supreme Court: The sheriff was also to deliver to each electeo representative a Certificate of his election. Nagistrates were to act in the absence of the sheriffs. All free male inhabitants could

21. Jounnals of Conventions at Danvilie, op.cit.,n.4 
vote. A rajorjty of elected members was to constitute a quorum. If the members wculd be unable to arrive on the first Monday in Novemoer, any three or more memiders could adjourn from day to day for five days. If a convention should not be formed at the end of the fifth day "trey may then adjourn to any day they ray think proper not exceeding one month." 22 The resolutions of this convention were to be read on each day of the elections. The president of the convention was to request the printer of the Kentuckv Gazette to publish the proceedines of congress and the convention, and 9 lso the recommendations for electing another convention. The president was ordered to wait on Tohn Brown wher he returneo to the district, thanking him for his faithful attention to the district's interest in coneress.

The sixth convention thus adiourned on July 31,1788 .

THE SEVENTH CONVENTION: The Sixth Convention had gjven the Seventh very wide and practically absolute powers, makine it the suprere ruler of Kentucky for the next fourteen months. Various shades of opinion resulted from the resolution of Z. Ioid. p.5 
the July, 1788, Convention delecating the seventh "Puli powers to take such measures for obtaining adriss jon of the district as a separste and indepondent member of the... (Jnion)..., and the navigation of the ...rississippi, as may spear most conducive to those important purposes."123 Thereupon a warm controversy arose over both the legal risht and the expediency of immediate separation from virginia. One faction contended that the only lawful way to procure separation as to apply acein to virgia and after procuring hor consent, apply to the Federal congress won it should come into existence the next year. ${ }^{24}$ The separatists contended that if Kentucky remaned part of Virgina it woll take years for the District, the state, end tre Federal Congress to agree on identical terms and time of separation and admission. If Kentucky were an independent state, however, contended this second school of thought, congress wpuld fear to refuse it proppt admission, lest it part with the Unitod States and form some comection with Great Britain or Spain. In that case the public lands north of the orio, upon which the Federal Covernment relied for credit, would be rendered unsalable, and probably the inhabitants there would follow Kentucky out

$23 \cdot \underline{I 010 .} \quad \mathrm{p} .4$

24.Bodley, op.oit., p.438 
of the Union. 25 The first group represented conservative opinion. It was opposed to illegal action. The later Federalist Party in Kentucky had its inception in this group. It included Ebenezer Brooks, Joseph Crockett, George Muter, and Thomas Varsha11. 26 The seconö group represented an impatjence with the delay in securing statehood. It stood for immediate action and included Wilkinson, Sebastian, Innes, Brown, and Wallace. 26

Ebenezer Brooks wrote a very length editorial in the September 13, 1788, issue of the Kentucky Gazette in which he presented the arcuments against separation. He declared that Virginia had always "cheerfully granted" Kentuoky's wishes. He said: "Revolutions in government are always dancorous, often fatal... In Repurics, this danger is heightened by the degree of licenciousness with which that form of eovernment is mixed." 28 He especially stressed the point that statehood could not pos $\theta$ sibly cive the people better protection against the Indians, for the country north of the ohio river, from whence the Ind-

25. Ibid. pp.438,439

26. connolyey and Coulter, op.cit., p.:61

27. Kentucky Gazette, september 13, 1788 
ian raids came, belonged to the Urited States Government, and, therefore, colld not be invaded by Kentucky troops without permission. Moreover, a new state government would increase taxes.

Geore Wuter submitted a lone letter to tho Octoder 18, 1783 is sue of the Kentucky Gazette which set the Kentuckians to thinking. He said that to form "a constitution of Eovernment, and organize the same, Defore the consent of the Lecislature of Virginia for that purpose is first ootained, will be contrary to the letter of the Act of Assembly entitled. an act for punishing certain offences, and vesting the covernor with certain powers." 28 This act said "that every person or persons who shall erect or establish any government separate from, or independent of the government of virginia within the limits thereof, unless by act of the legislature for that purpose first obtained, or shall execute any office under such usurped government shall be guilty of righ treason." Muter continued by saying that "the third section of the fourth article of the Federal Constitution (which has been

28. Mentucky Gazette, October 18, 1788 
adopted in Virginia) doclares that 'No new state shall be formed or erected within the jurisdiction of any other state nor any state be formed by the junction of two or more States, or parts of states, without the consent of the legislatures of the states concerned, as well as of the conpress. 1128 Iuter showed in this argument the impossiblity of the seventh Convention legally taking any action other than by the method heretofore pursued, of seeking an enabling act from Vjrginia and permission from Congress to enter the union. 28 rhe greatest effect of Wuter's letter was to put the people on their euard, and crystallize their thoughts ano ideas on the methods that should be pursued.

The November, 1788, Convention unanimously resolved to apply again to the Virginia Assembly for its consent to Kentucky's separation at a future date, 29 and adopted an adoress to the Assemoly praying for this and begging the"friendig interposition of the parent state with the Congress of the United States for a speedy admission of the District into the Federal Union,"30 and also "to urge that honoraile body in the most express terms to take effectual measures for procuring to the

29. Journals of Conventions at Danvilie, p.l1

30. IDId. p.20 
Inhabitants of this District the free Navigation of the River Mississippi, without which the situation of a large part of the comrunity will be wretched and miserable, and may be the source of futire evils." 30 As the Federal congress would not be organized u til the next Jear, no earlier application could be made to it for Kentucky's adrission. However, it was resolved "that a decent and respectful address be orepared, requesting Congress to take irmediate and effective measures for procuring the navigation of the river."

Tohn Brown, who had returned to Kentucky and was a member of this convertion, offered the following resolution, which is significant in view of the charge afterward made against him by Humphrey Varshall, that he was then conspiring with Gardoqui to detach Kentucky from the Union:

\footnotetext{
"Resolved, That it is the wish and interest of the cood people of this District to separate from the state of Vireinia and that the same be erected into an independent rember of the Federal Union." 31
}

The adoption of this resolution would have ruined Wilkinson's plan to make Miro think the convention favored Kentucky's secession from the Union, and action on it was post-

3.IDIC. p.12 
poned. 32 Two days later wilkinson sajd that since "it is the...desire of this convention, to pursue such measures as may promote the Interests... of their Constituents; but the...opinions which...divide the...people they represent, render it doustful whether they can adopt any plan which will embrace the opinions of all." ${ }^{33}$ He recommended, therefore, that " a comittee be apointed to draft an adaress to the... oople of the District... representing to them their true situation and solemnly calling on them to furaish the Convention at their next session with special instructions." 33

On the last day of the convention, ilizinson read his Nemorial to the Spanish King. "Of course...he read only such parts as suited hje own purpose;"34 but that not even his enemies in the convention questioned his motive in sending his memoriel to liarid was srown when president McDowell resumed the chair and the convention adopted the following resolution:

32. Bodlet, op, nit., pp. 443,444

33. Journels of Conventions at Danville, pp.13,14

34. Bodley, op.oit., p.444 
"Resolved That this Convention hjghly

approve the Address presented by Gen'1. Tames

Wilikinson to the Governor and Intenant of

Icuisiana, and that the President be re-

quested to present him the thanks of the

Convention or the regard whin he therein

manifested for the Interest of the western

country."1:5

Wilkins on had managed to make the minutes of the

Convention a convincing record to prove to liro his influence

in Kentucky. His scheme was complete when tre Convention

"ordered, that the printer of the Kentucky Gazette be re-

quested to puolish the proceedings of this convention. "36 The

Cazette puolisbeo the minutes and wilkinson promptly sent a copy to miro. 37

After the November Convention Wilkinson pluated deply into the ousiness of ouyine rentung produnts and seling them in liew unleans. Fowever, his means wene small and his debts many. He had come to Kentucky practically bankrupt. His coveted trade with New Orleans prover far less profitable than he expected and soon involved him deeper in debt. Besides in-

35. Journals of Conventions at Lanville, p.20

36. Io id. $\mathrm{p} .21$

37. Bodley, op,cit., p.445 
numerable difficulties and delays in hiring men, ouilding boats, and buying proouce on credit, his boats coing down the river were exposec to many mishaps and their cargoes to injury and pillage; while havine the proceeds of his sales in New or leans brought back to Kentucly involved much expense, and required great care and secrecy to prevent loss. Within ten months after the November, 1788, Convontion, Wilkinson was asking Miro for 18,500 , as the first installment of annual remittances for bribing many prominont Kentuckians to become his co-conspirators and pensioners of Spain. The Wadrid Eoverment refusea to comply with this sugestion. ${ }^{38}$ from this time forth, although receiving yearly a pension from Spain and still professing to further its design to detach Kentucky from the Union, his political activities nearly ceased, and he again entered upon \& military sareer.

PHE EIGHTH CONVENTON: The recommendation by the Novemoer Convention that another one be called for August, 1789, was not followed, because shortly after the adjourment, nevs reached Kentucky that the Virgjinja Assembly on Lecember 29 , 1788, had passed a third act of separation, 39 and fixed another date for

38. Ioid. pp.445, 446

39. Hening, op.ojt., Vol.XII, pp.788-791 
cother convintion. This third act materially altered the second one, and creatly to the prejudjce of the Kentucky people. It hampered Kentucky's control of its ungranted land by the followine clause:

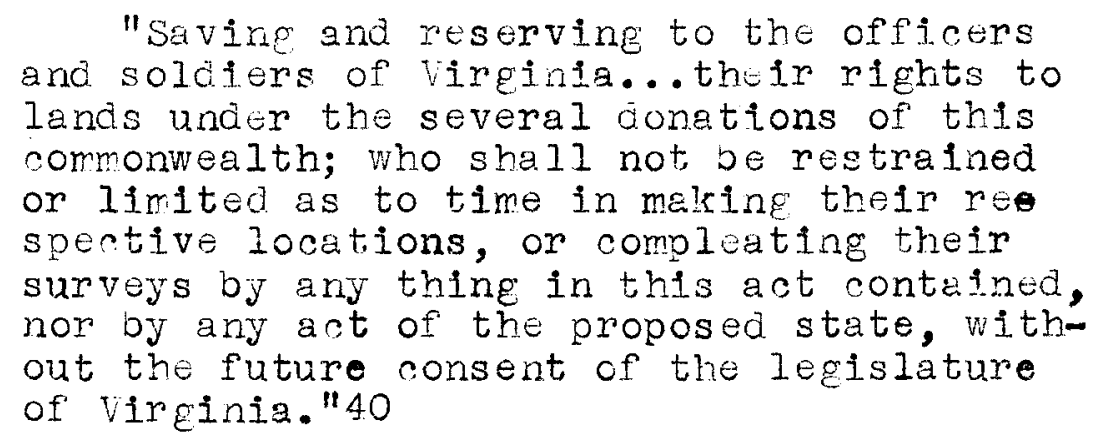

The Kentuckians protested that this clause would degnive their new state of its most valuable asset, oy rendering $\therefore$ forever powerless to sell to advantage any of its many millions of acres of ungranted lands; sjnce, without virginia's consent to the sale, any purchaser and his heirs could be forever liable to lose them to claimants under her military donations. 41 This new act also provided for another (eichth) convention to be held July 20, 1789, to decide again on the expediency of Kentucky's separation from Virginia.

The Fighth Convention passed the following resolut-

40. Ijtte II, op.cit., p.108

41. Jcurnals of Conventions at Danvilie, p.31 
ions:

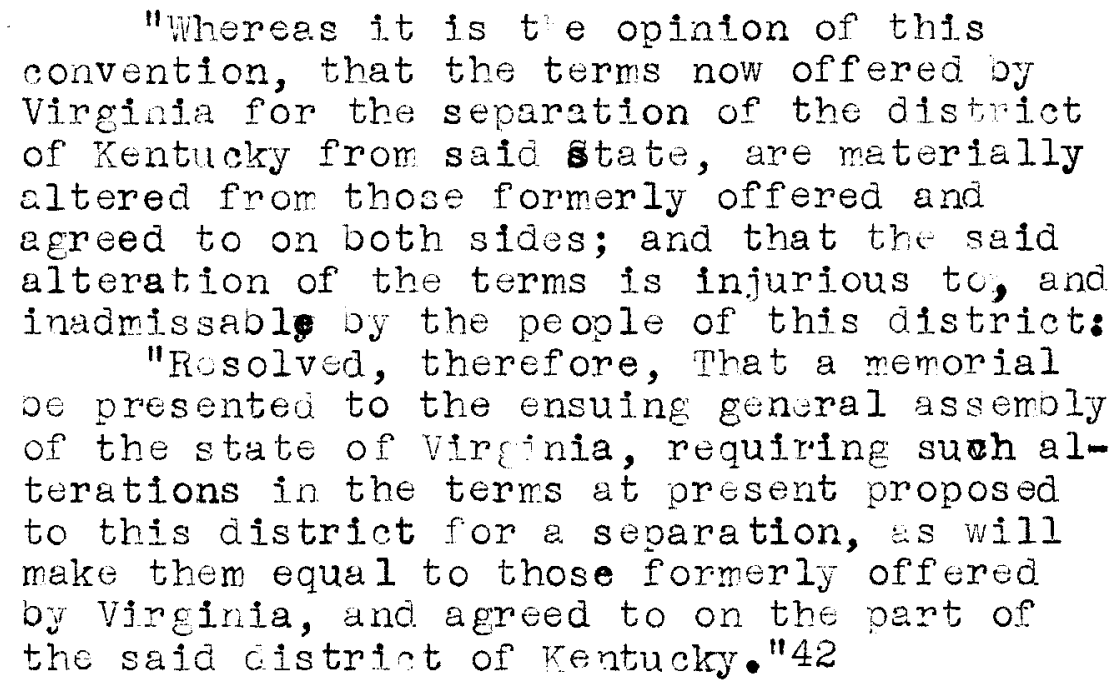

The memorial was accordingly drawn up and forwardid to the Assemoly. The leaders in Virginja lost no time in considerine 1t, and, as socn as the forms of legislation could be cone through $j$ th, the final act of separation was passed on December 18, 1789. 43 This fourth act repeelen tre conoxious ciausos jn the preoectng one, but made stil wothr condition hardly less unjust. This required the Kentuckians alone to bear the exoense of the two expeditions of Clark and Logan in 1786. This act also authorized the people again to elect representatives to met at Danville on July 26 , ensujng, to deter-

42. Journals of Conventions at Danville, p.37

43. Hening, op.oit., Vol.XIII, pp.17-zl 
mine, a fifth time, the inclination of the people to separate from vireinia. If the convention approved the provisions of the "Fourth Enabling Act," they were to fix a day posterior to Novemoer 1, 179], when the authority of Virginia would cease. However, jefore this date, the United states Eovernment had to assent to the eroction of Kentucky into a state, had to release Vireinia from all her federal obligations arising from Kentucky boing a part of vircinia, and had to agree that Kentuckr woulo immediately, after the day to be fixed after November 1, Ir9l, be admitted into the Federal Union. According to the act, the convention would have authority to take mea wres for the election and meeting of a convention with porer to establish a fundamental constitution of government. This constitutional convention mas to meet sometime between Noremoer 1 , I790, and the day fixte for the cosing of the authority of Vinging.

Elections were held in conformity ith the preceding act, the representatives chosen met at Danville, July 26, 1790, and on the third day decided on the expediency and propriety of a separation on the terms now offered by vircinia:

"Resolved, That it is expedient for, and 


\begin{abstract}
the will of the good people of the District of Kentucky that the same be erected into an independent state on the terms and conditions spccified in an act of the Vireinie Assemoly passed the loth day of December (1789)entitled an act concerning the erection of the District of Kentucry into an independent state. " 44
\end{abstract}

This resolution passed by the narrow majority of twenty four to eighteen votes. By comparing the name of the voters ${ }^{44}$ ith

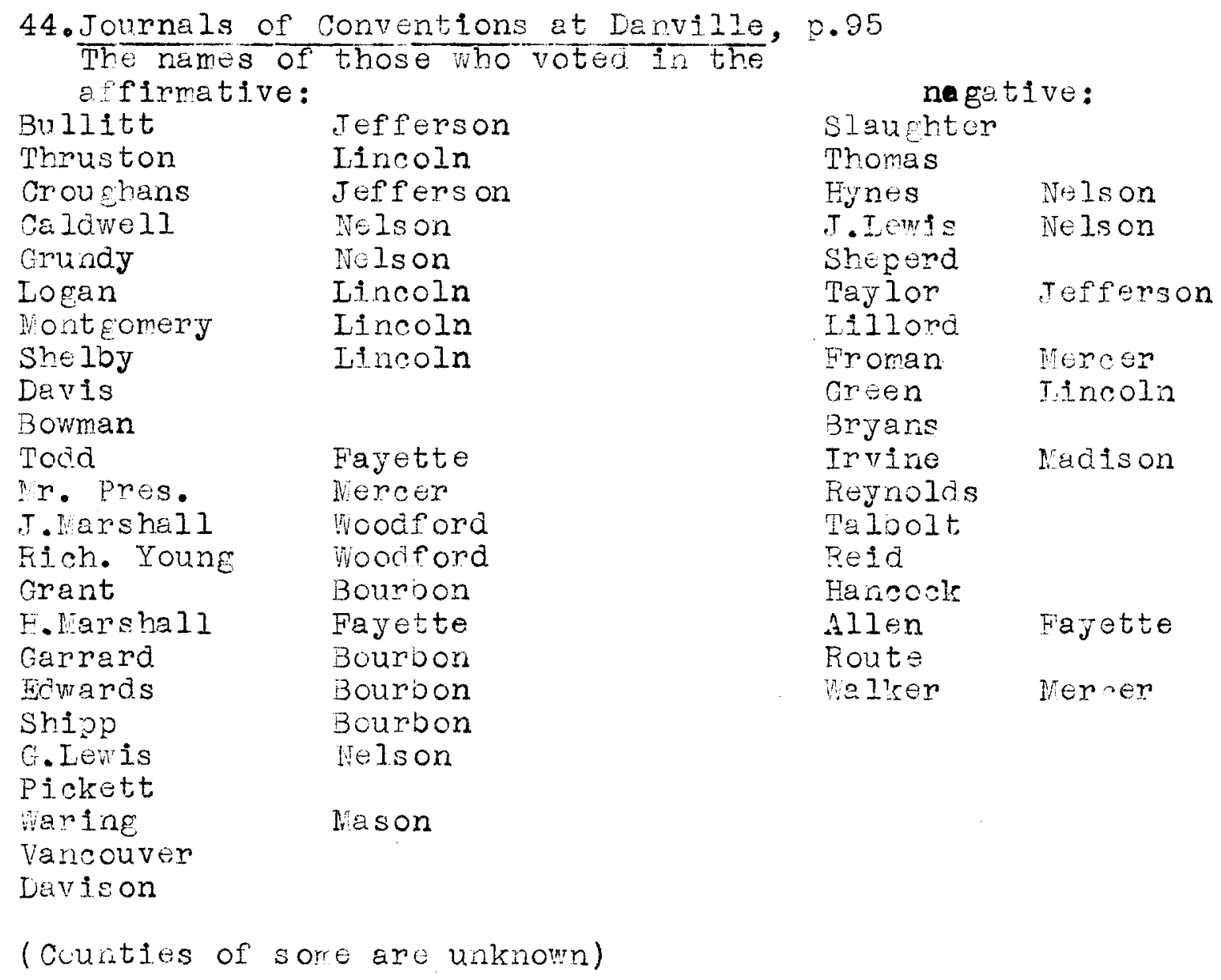


the counties they represented the writer is led to the conclusion that it is difficult to speak of this or that section being for or acainst separation from vircinia on the terms of the Forth Enabling ect. In snj one county or section the votine representatives are divided. Even in Fayette county, the heart of the Bluegrass, the vote was only nine to five in favor of separation. The opposition scems to have come mostly from the outlying counties, especially Nelson and fercer. Sentment for continuine as a part of Virginia had increased after the storm of the prececing year had olom over. A reaction had recently set in acainst separation on eny terme. 45 The poople had stopped talking aoout separation, to e great extent. Natraniel Rjoharoson in a letter to John Breckimiage, February 11, 1790, said, "oum Indian affairs seem to engage the attertion of tho common-people \& a Separation that of the leadine Men." Iotn Brown expleins the opposition thus: "The voice of the minority was the last protest of unalterale attachment to their native Virginia." ${ }^{47}$

A cormunication to the legislature of Virginja was

45. Connelley and Coulter, op.c1t., p.278

46. Breckinridge VSS, (1790), quoted in IBid. p.278, note 47. Brown, op.cit., p.zzl 
fremed, informing the mother state that her legislation for separation rad $0.6 \mathrm{k}$ soepted, and expressing the thanks of the people of Kentucly for all the care and interest shown by vireinia. The communication expressed the hope that that smae friendy spirit would continue after separation. 48

A communjation "To the President and the Fonoraible the congress of the Unitod States of America," 49 was also adopte3, asking a sunction of the compact entered into between the peoples and an admission of Kentucky into the Union, Tune 1 , 1792. The memorial said that the Kentuckians were "warmly devoted to the American Union; that they have with great hazard and difficulty effected their present setilements; and that the population and strength of ientucky are sufficient for statehood." 50 The memorial begged Congress to act before Novemoer 1, 1791. After providing for the election of dalegates to a convention which they called to meet in April, 179\%, and to which was comritted the preparation of a state constitution for Kentucky, the Ninth Convention aissolved.

48. Journals of Kentucky Conventions, 0.45

49. Ibid. p.50

50. Ibia. pp.51,52 
CORGEESS A PROVES: On Decemoer 9, 1790, the ientucky memorial of Tuly, 1790, was communicated to the Uited States concress for the first time. 51 Ta admission of rentucky was authorized on Feoruary 4. Five cays later the appeal of vermont for statehood was received. New York, which had claimed this territory since before the Fevolution, now expressec ite willineness to recognition of the state under a constitution already in effect. vermont was admitted Narch 4, 1791, 53 less than a month after apply $1 n g$ to congress. Kentucky vias admitted Tune 1, 1792, almost a year and a half after making application. In considering the question of representation in rongress, the congress approved an act, on Feoruary $z 5$, 1791, which sald "that until the representation of Congress shall be apportioned according to an actual enumeration of the inhabitants of the Uniteo States, the States of Kentucky and Vermont shall each be entitled to choose two representatives. 55 The writer interprets these proccedings thus: the Northeastern Stat es had en-

51. The Debates and Proceedings in the Congress 0 the United 52. To10. p. 1798

53. IDic. p. 2374

54. Toid. pp.2372,2373

55. Ib1a. p. 2375 
joyed a rajority in the Continental congess and they were determined that the admission of another southern state should not destroy their position. Therefore Northeastern politicians orought verront corward. Evidence to support this interpretation may be found in a letter to ceorge futer from John Brown, dated July 10, 1788. 3rown wrote thus:

"I expect you have heard the determination of Congress relative to the separation of kentrckj. It was not in ry power to obtain a decision earlier than the 3 ra instant. Great nnt of the winter and spring, there was not a representation of the states sufficient to proceed to this business, and after it was referred to a Erand comrittee, they could not be prevailad upon to report, a majority of trem bein opoosec to the measure. The eastern states would not, non do $T$ think they orer will ascert to the acmission of the distondot into the union, as an independent stete, unless Vermont, or the province of Naine, is brought forward at the same time. The change which has taken place in the general government is made the ostensible objection to the measure; but the jealousy of the growing irportance of the western country, and an unwillingness to add a vote to the southern interest, are the real causes of

, opposition; and I am inclined to believe that they will exist to a certain degree, even under the new eovernment to which the application is referred by Congress." 56

56. Bodley's Introduction to Iittell's op.cit., f. $\times x \times 1$ 
The Northeasternors were unwiling to admit Kentucky until it could be arranged for a now northeastern state to come into the Union.

Against this interpretation, it may be argued that the admission of Kentucky was approved before that of Vermont. The Vermont government had been in actual existence since 1776. Therefore it could come in imrediately after congress actod. Kentucky could not come in, according to acts of congress and of Virginia, until 1792, because of the necessity of having a constitution. We would neej to know the inside story before saying which interpretation is correct. 
SHAPTER VI

THA TENTH (CONSTTTUTIONAL) CONVENTION, APRII 2,1792 
CHAPTIER VI

THE TENTH (CONSTIIUTIONAL) CONVENIION, APEIL 2,1792

PRELIRTNARY IISCUSSION: Sufficient tire was given in the call of the Tenth, or Constitutional, Convention, for a thorough discussion of the principles of governatent by the people of Kentucky. The Kentuckians, therefore, had an opportunity to formulate their ideas on what they wanted to include in the First Kentucky Constitution. All available agencies and means of comrunication were usec - informal discussion, formal debate in the Ianville political club, and incirect conversation through the Iertucky cazette.

The following questions arose concerning the organization of the state government and the government's attitude toward existing institutions:(1) Shail there be a one-house or a two-house lecislature?, (2) How shall representation in the state legislature be apportioned?, (What shall Kentucky's attitude be toward the institution of slavery?, (4) Who may vote?

(1) Iegislature. Perhaps no constjtutional proolem 
came up for more thorough and prolonged discussion than the question as to whether or not the legislative power of Kentucky shovld be vested in one or two houses. In several. issues the Kentucky Gazette spoke against a two-branch legislature. ${ }^{2}$ It was argued that a bicameral legislature would be unworkable, as one house would most certairly olock the other in whatever legislation might be attempted; that one group of people out in the state would side with one house for a law and another group would side with the other house against the law, and that as a result the strife of the lecislative chamber would be transferred uroadcast over the state to the destruction of the puplic peace and tranquility. 3 In tre election of delegates, Bourbon County instructed her representatives to vote for a legislative body of one chamber, sayine "that the legislative power of this state ought to be vested in a single house of representatives." 4 The Danville Political club favorec the bicameral arrangement as shown in the minutes for Tuly 7, 1787.5 This or Eunization had made a

1. Connelley and Coulter, op cit., p.28l

2. The Kentucky Gazette('n the Filison Cluo, Loulsville, Ky, Reproauced by the photostat process), octooer 15 and ontober 22,1791

z.IDid. October za, 1791

4. Toid. Ontober 15, 1791

5. Speed, op.eit., p.139 
careful critical study of the Federal constitution and was in favor of the organization of the legislative branch as set forth in that aocument.

(2) Representation. The question of the maner in wh-ch representation should be spportioned also care up for much discussion. The vireinia method of fixing representetion by counties, refardiess of population, ald not a peal to the Kentuckians. Thej felt that this method did not represent the principles of equality and democracy. The Danville political club aiscussed this question and came to the conclusion that representation by numbers of inhabitants, not counties, ought to be preferred. 6

(3) Slavery. The question of slavery also presented a proplem. The religious elements of the population were adverse to a perpetuation of this institution. Emancipation parties were formed in many of the churches. The imprudence of the abolition preachers, in declaring against slavery, in the presence of the negroes, ceused insuoordination amone the

6. Ioid. p. 1.14 
slaves, and theroby disturbed the peace of society.

Seven of the forty-five men of the convention were ministers, of whom three (Baily, Smith, and carrard) were Baptists; three (Crawford, Swope, and Rice) were Presbyterians; one (Kavanaugh) was a Iethodist. Although David kice resigned his seat in the Convention before the final vote was taken, Harry Innes, eiected to take his place, supported the emancipationists. 8

(4) Suffrage. The Danville Political Club resolved that some qualifications other than merely freedom ought to be required for tre suffrage. It does not appear whether property, or ecucation, or both were deemed essential by the club. 9

The man who contributed most to the First "entucky

7.T.H.Spencer, A History of Kentucky Baptists (1769-1885) (T.R.Baumes, 1885 , Cincirnati), VoI.I, p.185

8. Asa Earl lartin, The Anti-Slavery Movement in Kentucky Prior to 1850 (Filson Club Puolication No.29) Standard Printing Co., Louisville, Ky.,1918, p.17

9. Speed, op.cit., p.125. At this time in all the thirtcen states property owmership or tax payment was required, exceptine that in Pennsylvania and Frode Is land the eldest sons of freeholders could vote without being taxpayers. In vermont, all law-abiding male citizens had the voting privilege. 
Constitution was George Nicholas, who made his first appearance in Kentucky politics as a member of the Tenth Convention. He was thoroughly familiar with constitutions and constitutional practices. Ho had sustained debate against patrick Fenry and ceorec liason in the vircinia Conwention that ratifiea the constitution, and shared with James Madison the credit of earrying the vote to victory. The First Kentucky Constitution may be larely attriouted to the work of Nicholas. Brown says: "He was the principal debater on the floor, and the principal dreftsman in compttee." 10 Speed, however, refuses to give Nicholas all the credit, saying, "The constitution was the work of a convention, not of one man." ${ }^{11}$ George Nicholas' ablest opponent in the Tenth Convention was the Reverend David Rice, his colleague from liercer County, an eminent presbyterian clereyman, who opposed slavery. Other leading memoers were Harry Innes, Benjamin Logan, Alexander s.Bullitt, Matthew fialton, Caleb Wallace, Robert Breckinridge, and Isaac Shelby. All, in fact, had been chosen for their ability and thorough knowlecge of the needs of the Kentucky people. The graster portion of them had veen in Kentucky frum eight to twelve

10. Brown, op.cit., p.128

11. Speed, op.nit., p.162 
years. Logan had been a tower of strength to the settlements from their oeginning in 1775, a period of seventeen years. Nicholas came out in 1788, four years before the convention.

The Political Club eppointed a committee to araft a form of government adapted to the needs of Kentucky as early as February 17, 1787. Probably this was revised an 1792. The convention was engaged upon its work only eighteen days, from April 2 to April 19, 1792. This would indicate that some persons had hitherto been engaged upon that important work and had laid the fundations. "The study of the Federal constitution in the poljtical club bore its natural fruits in the construction of the one of 1792 for kentucky."

II. THE SIAVHWY QUESTION: Slavery was perhaps the most controversial question in the constitutional Convention. This institution was jntrocuced into Kentucky with the earliest settlers. While the majority of tre pioneers were very poor anc consequently non-sleveholoers, hero was, during the years followine the kevolution, ar influx of prosperous settlers,

12. Ioja. p. 163 
partionlarly from virfinia, who broutht a number of slaves ith them and engaged in the culture of tobacso on a consjderable scale. It wi not, however, until the Indian danger had been removed and frontier conditions in Kentucky hac given place to cormercial activity and to planting for proftt as vell as for subsistence that the number of Negroes materially increased. Their numerical strength cannot be definitely determined previous to 1790 when, according to the first federal census, they constituted 16.9 percent of the totel population of Kentucky.

The leading slaveholding section in 1790 was the centrel part of the state, comronly known as the Blue Grass region. During the next three decades slavehold ${ }^{2}$ ng extended eastwara and south eastward to the mountainous district and quite generally over the western and scuthern parts of the state.

While the introduction of slavery into Kentucky was inevitable in view of the circumstances of settlement, concitions within the state were not particularly favorable to its 13. Iartin, p.cit., p.7 
development. Adjocent to the free states of the old Northwest, Kentucky found herself in competition with the more economic system of free labor. The exhausting nature of tobacco culture was destined to render the planters keenly conscious of the handicaps under which their agriculture labored in comparison with the agriculture of the states beyond the chio. ${ }^{14}$ Conditions that had operated to bring about emancipation in Penns yvania and the states to the northward soon exerted a similar influence in entucky and the result was an anti-slavery agitation which took the form of a movement for some plan of gradual and compensated emancipation. 14 Impediate emancipationists and Carrisonian abolitionists were never mamerous in Kentucky and the few existing there were almost entirely among the non-slaveholding class.

During the period of the Revolution and the early years of the Republic, sentiment in the country as a whole was unfriendy to the institution of slevery. It was regarded as inconsistent with Christian civilization and out of accord with the eneral principles of liberty for which the Colonists had contended. The feeling that it was injurious to so-

14. Ioid. p.10 
ciety was in no sense dipendent upon sectional lines. Its existence was lamented by such men as ashington, Tefferson, pronroe, Madison, Franklin, Harilton, Jay, and Aders. There was a general ropret that the institution had ever been planted in America ano it was hopod that in time st would be abanconed.

While Kentucky rerained an integral part of Vircinia, there was little opportunity for a eeneral expression of the sentiment of the people as to slavery; but upon one occasion their opinion was indrectly voiced in a debate before the Danville political club. At one of the meetings in 1788, the new federal constitution, which had recently been suomitted to the states for ratjication, was taken under consideration. Sentirent was unanimous against the clause relatine to the irportation of slaves because it deprived congress of the power to prohibit the forelgn slave trede before 1808. It was the opinion of the merbers that congress ought to be given power to cut off the odious traffic at any time it should choose to do 15

so. It is irportant to notice that the poljtical club

favored irrediate abolition of the slave trade, not slavery itself. The erclusion of the slaves increased the value of

15. Speed, op.eit., p.151 
those born here. A valuable part of the estate of nearly every member of the club dcuotless consisted of slaves. Their attitude toward slavery is not surprizing.

It was Devid Rice, the father of Presoyterianism in the west, who took the first conspicuous step toward securing the abolition of slavery in Kentucky. (Comire to Kentucky from Virginia in 1783, he became the first teacher in Transylvania Beminary.) On the eve of the meeting of the convertion of 1792 to frame a constitution for Kentucky as a state in the Union, he published, und $\mathrm{cr}$ the signature of "Philanthropes" a pamphlet entitled "Slavery, Inconsistent with Justice snd Good Policy." I8 In this he spoke freely of the comparative unoroductiveness of slave property. He undertook to answer objections that were comonly raised to emancipation, especially those drawn from the scriptures, whinh were oeing used to iustify slavery. In conclusion, he proposed that the coming convention sholld "resolve unconditionaly to put an end to slavery

16. Bodley, History of Kentucky, op.cit., p.43I

17. R.H.Bishop, Outline of the Church in entucky Containing Nemoirs of Lavid Rice, pp.114,385,417,95

18. Io1d. p.385 ff. Eive this parphlet in full 
in Kentucky." ${ }^{19}$ Not content with mere argument, be succeeded. in being elected a delegate to the coming convention.

The Baptist attitude toward slavery is best expressed in a resolution of the Baptist General Comrittee in August, $1789:$

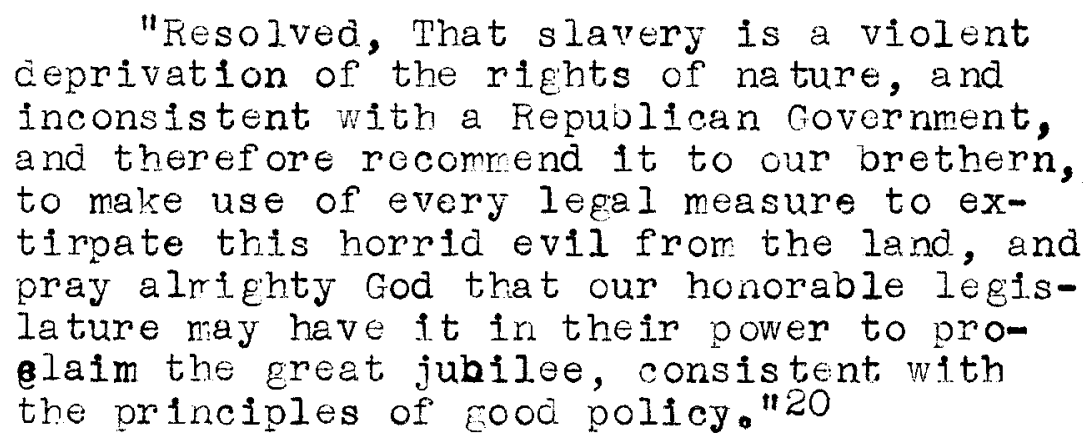

Provisions regarding slavcry were put before the convention for adoption. These deserve notice as showing the earliest expression of the Kentucky pioneer democracy on slavery. These were designed to make slavery as mild and as humane as possiole. They nevertheless made it virtually perpetual because of the difficulty of amenoing tre funomental law, or of cranting nompensation.

19. Ibia. p.

20. Spencer, op.cit., p.183 
The most remarkable clause of the slavery article conceded to the Iegislature the power to emancipate slaves upon corpenseting the owners. The power of the Legislature to pass an mancipation law was only limited by the following provision:

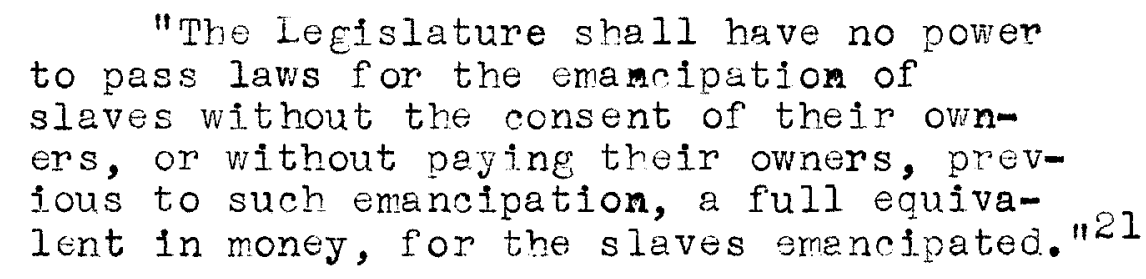

The emancipation sentiment cisplayed by this provision strongly contrasts with that prevailing a half century later, when southern slave owners were incensed by numerous abolitionists' demsind for liberation of the slaves without compensation to the owners. The just principle here stated was the same repeatediy advocated by Abraham Iincoln, who justified his emancipation proclamation of 1863 only as a military necessity. Temple Bodley somrents as follows:

"Unless justified by such an overwhelring public necessity, to deprive an owner of any of his lawful property, without fair comporisation, is repugnant to every

21. Iournals, op.cit., pp.81,82 


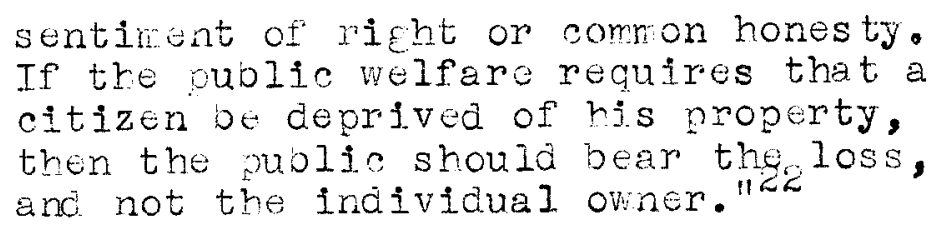

Concorning the importation of slaves, the article

provides that tre Legislature:

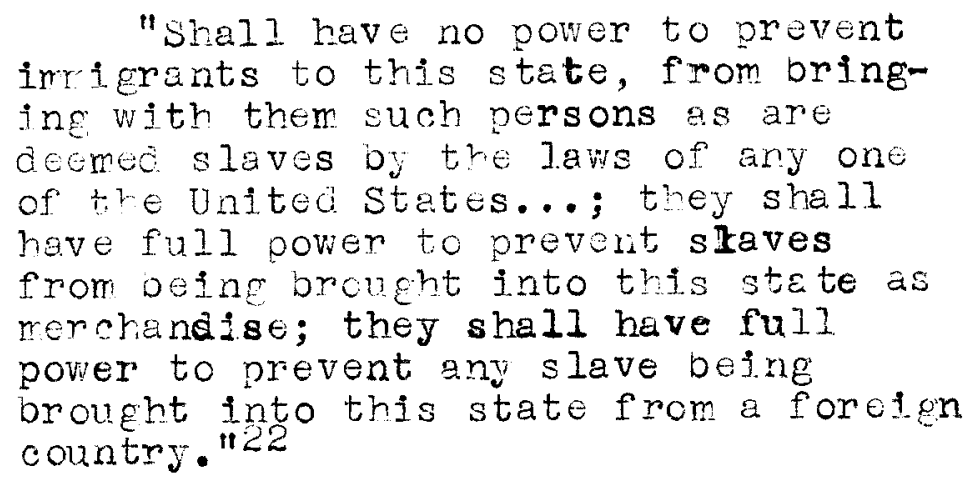

Ooviously the maln reasons for the preceding provisions were to protect slave-owners within Kentucky and to exclude slave trade. Nearly every state prohioited slave imports - for sooiel and economic reasons. Such laws served as a sort of protective tariff.

Humane sentiments were responsible for a provision that the legislature could:

22. Bodley, his tory of Kentucky, pp.490,491 


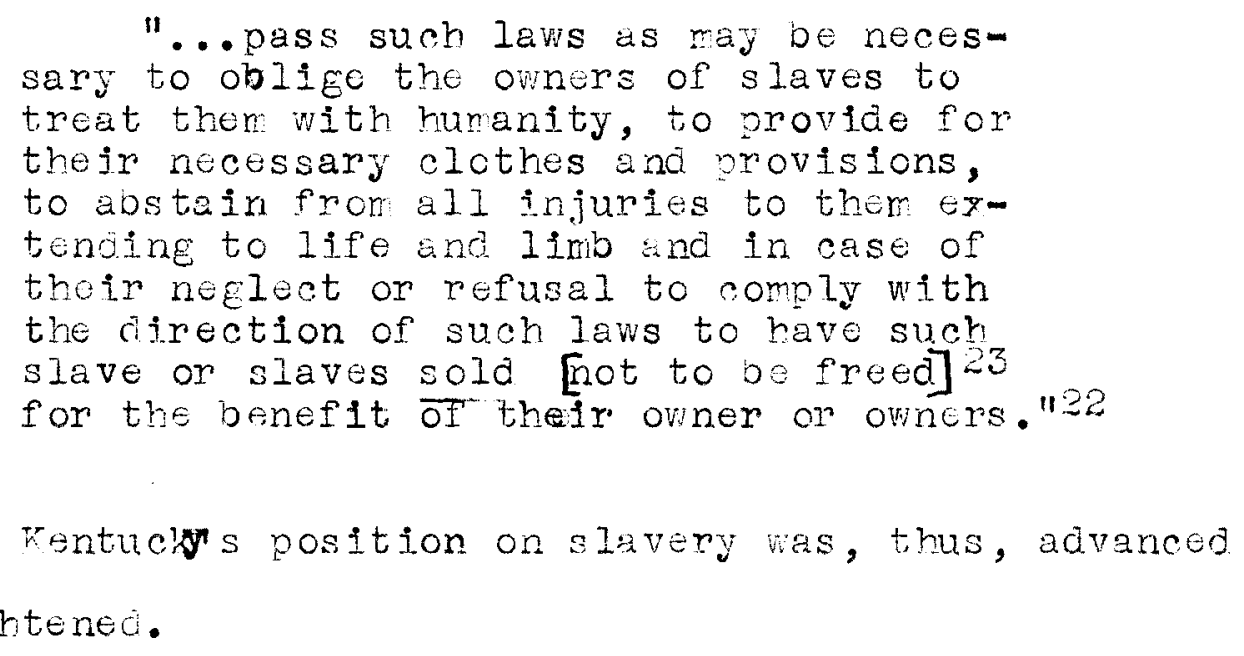

The constitutional provision fixing slavery in the state was ably supported by Colonel Georee Mioholas. After a thorough discussion which lasted for a number of days, the grestion wus put to a vote. A motion was mede by lin. Taylor of vercer county and seconded by $\mathrm{kr}$. Snjth of Bourbon County to expunge the Ninth Article of the Constitution respecting slavery, which wies negatived and the yea's and nay's on the question were ordered to be entered on the Tournals. This was the only case where the ayes and noes were recorded in the Journal. The result of the vote to expunge Article Nine was: ycas, sixteen; nays, twenty-six. The majority vote of Tefferson, Lincoln, Madison, Nelson, and Woodford Counties was

23. Writers' brackets and underlining 
against expunging Artiole Nine; that of Bourbon, Fayette, Mason, and hercer conties was in favor of expunging Anticle Nine. Woodford, Fayotte, Tofferson, and lenos had the hichest percentage of slaves to whites, while Noson, Nelson, Bourbon, liadison, and Incoln couties had the lowest percentage of slaves to whites. The following table reoresents the frue and slave population in 1790 of each of the nine connties into which Kentucky was divided at that time and the votes cast in the constituticnal convontion two years laton for and a duint slavery:

2790 Whites slaves

$S 1 \mathrm{VE}$

Votes in convention Perrent, Pro-slave Anti-slave

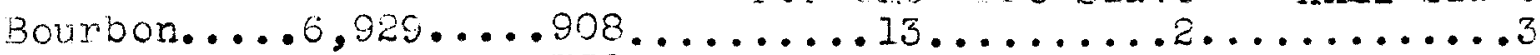

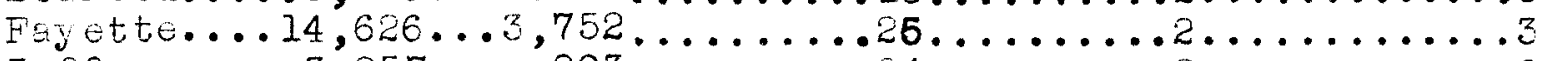

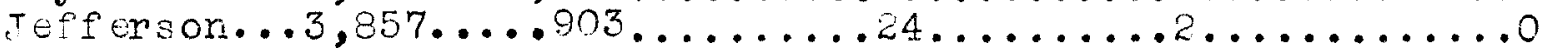

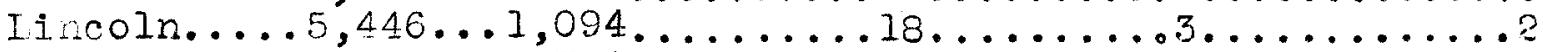

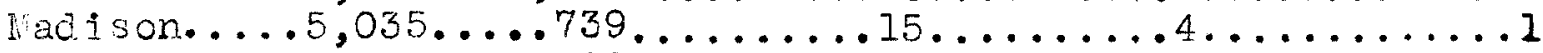

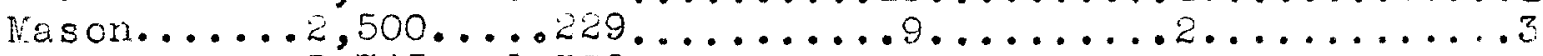

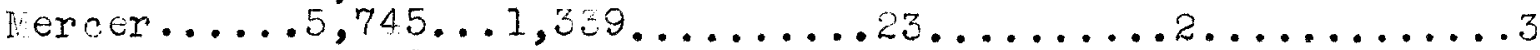

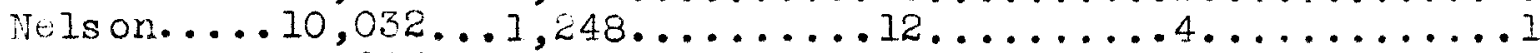

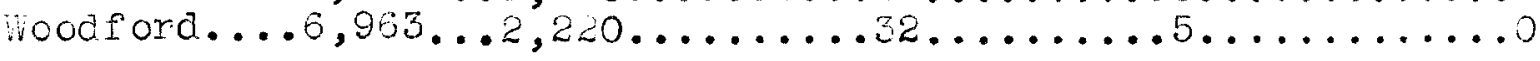
Totel $61,333 \quad 12,430 \quad 20 \quad 26 \quad 16^{65}$ 24. Nartin, op.oit., p.16

25. It is difficult to interpret the weaning of this voto. It is unlikely that the mombers of the convention fror Fayette and other slave counties had seen so ruch of the evjls and ecorcmic waste (sis compared ith the free s.stem in the old Nortbwest) of slavery, havirge such a large percentage of slaves to whites, that they were ready to take a stand against the continuance of the institution. Perhaps the delegates from Fayette County opposed the provision for emancipation as set forth in Artjcie Nine. However, there is no evidence to support this interpretation. 
Three of the delegates, vallace of Woodford county, Vialton of Nelson Couty, and Sebastan of Jefferson County, who were generally regarded, prior to the meeting of the convention, as emancipationists, supported the constitution as proposed by the comittee. This change of attitude has been attributed by Tohn Nason Brown and others to the influence of Nicholas, although no evidence has been produced to support the nontention.

III. FOFI OF GOVERMANT: The constitution-makers in the Tenth Convention provided that the powers of fovernent be divided into three distinct departments - legislative, executive, ana juoicial. 'ive lecislative power was vested in a ceneral Assembly consisting of a Senate and a Fouse of Fepresentatives. The Representatives were to de chosen amually $D_{y}$ the qualified electors of each county on the first thesclay in may. All free rele citizens, twenty-one years and clcer, having resided in the state two years or the county fin whin they expected to vote one year, could vote. All elections were to be by ballot. The elections

26. Brown, op.cit., p.230

27. Tournals of Conventions, op.est., p.91 
couló be continued for three dags if necessary. Wonld-be reoresontatives ene to be et least tonty-four jears or age, nitirens of the state tro yosrs, and inheojtants of their res ective contios for six rontrs. Repesentatives were to be eonortioned arone the several counties accoriting to the numer of free males over twenty-one years of age. The number of representatives could never be less than forty nor more tran one hunored. Counties hereafter erected could not oe entitled to separate representation until a sufficient numoer of free male inhastants above twonty-one years of age should reside within such coun$<8$ ties.

However, democres in kentucky dia not po unorided. The covernor, the senators, and the judges were removed from direct election oy the people. The governor was to be elected D. an electoral college. The electors had to be three-ycar residents of the state and not under twenty-seven years of age. The electors were enjoined to:

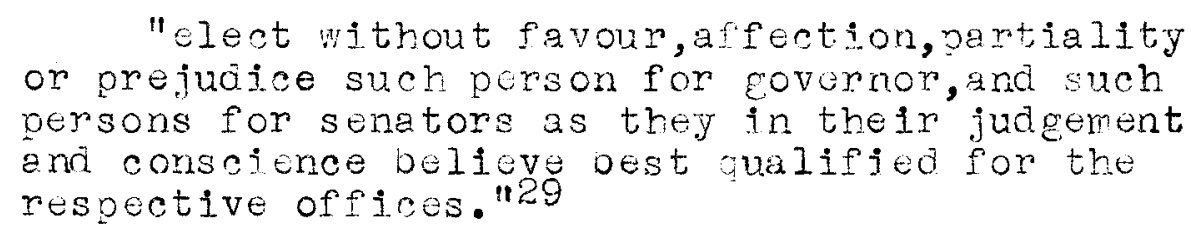

28. Ioungals of Conventions, op cit., pp.31,88

29. Ibid. pp.83,84 
All persons qualified to vote for Representatives were to elect electors of the senate and the overnor. The number of senators was fixed at eleven. For every additional cour Representatives, one new senator was to de added. "Thus the senators were inairectly apportioned according to population. Until the number of counties should equal the numoer of senators, at least one should be elected from each couty; thereafter they were to be elected at large. Senators served a term of four years, one-fourth retiring at the end of each year. The method of choosing state senators and the Covernor had been proposed by the Lanville political club four years pefore the convention adopted it. 31 This was prooebly due to the fact that the Danville Political Club had studied the United states constitution very carefuliy.

Each house was to choose its speaker and otrer officers. The constitution did not provide for the election of a lieutenant-governor; out, instead, the peaker of the senate

30. Ibid. 0.83

31. Speed, op.cit., pp.147,148,163

32. Later when the first Legislature met on June 6, 179:, Alexander scott Bullitt ws chosen spoaker for the senate, and Robert Breckinricke, speaker. for the House of kepresentatives. 
succeeded to the covernorship in case the governor were rendered incepable. The senate was also to choose a speaker pro tempore to succeed the speaker if and when he supplied in the absence of the covernor. A majority of each house was to constitute a quorum. Senators and Representatives cold d not holc any other civil offices in the state. 33 Nor could ministers of religion, memoers of Congress, or other persons holding offices of profit under the United States or rentucky, except attornies at law, justices of the peace, militia officers, ana coroners, be merbers of either house. ${ }^{34}$ All bills for the raising of revenue were to originate in the House of Representatives. 34

The executive power was vested in a Governor, who was to de elected by an electoral college. He was to serve four years from the first day of June following his election. He was to be at least thirty years of age and a citizen of the state for two jears. The governor was to be corrander-inchief of the army and navy and of the militia of the comron-

33. Speed, op.cit., p.86

34. Ibic. p. 87 
wealth. He had the power to appoint, with the advice and consent of the Senate, all officers whose appointments were not 35

otherwise provided for. He had the power to grant reprieves and pardons. He was to inform the General Assemoly, from tire to time, of the state of the commonwealth, and to recommend to their consideration such measures as he might judge expedient. The constitution said trat: "He shall take care that the laws de faithruliy executed." ${ }^{36}$ A two-thirds vote of both houses was necessary to pass a bill over the governor's veto.

In impeachment proceedings, the House of Representatives was empowered to oring the charges; the senate acted as the jury; ${ }_{38}$ and a two-thiras vote by the senate was necessary to convict.

The judicial power was to be vested in one supreme court, to be called the court of Appeals, and in such inferior courts as the legislature ray, from time to time, see fit to establish. The judges were appointed by the governor. The

35. Ioid. p. 89

36. I010. 2.90

37. Ioid. p. 88

38. I01d. pp.91,92

39. Ibid. p.92 
Court of Appeals was to have original and final jurisoiction in all cases respecting the titles to land under the then present land laws of Virginia.

Sheriffs and coroners were to be elected by the people of each county.

The freemen of Kentucky were to be armed and disciplined for its defense, but conscientious objectors could pay an equivalent for personal service. The field and staff officers of the militia were to be appointed by the governor, except the battalion staff officors who were to be appointed by the field officers of each battalion. The officers of companies were to be chosen by the persons enrolled in the list of 40

each company.

The Constitution specified that:

"All laws now in force in the state of Virginia, not inconsistent with this Constitution, which are of $a$ general nature and not local to the eestern part of that state, shell be in force in this state until they shall be altered or repealed by the legislature." 41

40. Ibid. p.95

41. Ioid. 0.96 
The compact with Virginia, that is, the Nonth convention's acceptance of the "Fourth Engoling Act," was to be a part of the First Constitution.

The framers of the First Kentucky Constitution did not consider their work as permanent. It was to be an exporiment in government. Anticipating that it might not sait the people in all of its parts, the Tenth Convention provided a special method of ascertaining the popular will after the document had been given a trial. It was provided that the peoplo might take a vote on the advisability of calling a new constitutionel convention in the election of 1797, and, that if the majority were in favor of a convention, then the electorate should vote in the following general elections of 1798 , and If again the majority were favorable, the logislature shonld cell a convention in 1799 to revise or remake the constitution. There was another method provided of remaking the constitution whereby a majority of two-thirds of ooth houses of tre legislature micht call a constitutional convention without a vote of the people.

To summarize, the First Kentucky Constitution had 42. Ioid. p.99 
sore new and unusual features. It doparted from the traditional eastern prectice by requiring no religious test of any kind for office holding. Representation was to be based on population and not on counties as was the case in Virginia. Kentucloy, (with Vermont), preceded the rest of the world a guarter of a century or more in eranting a full and free suffrage to all. white men regardess of the amount of property owned.

The United States House of Kepresentatives in an address to Washington, November 10,1792, characterized the Tentucky document:

"as partioularly interesting since besides the irmediate benefits resultine from it, it is another auspicious demonstration of the facility and success ith which an onlightened people is capable of producline for their own safety and

Thus Kentucky took her place as a memoer of the Federal Union, Tune 1,1792. The new government of the Commonwalth ras formally inaugurated Tune 4, 1792 , in Iexington, Kontucky. In the precedine Vay, Tsaac shelby had been elected as the first governor. In the annals of constitutional goverment Kontrixy has no counterpart. For eight years she had lapored through ten con-

43. J.D.Richerdson, A Compilation of the Nessages and Papers of the Presidents, $1759-1797$ (1896-99), Vol.I,p.132 
ventions, a record that has never been approximated from that day uitil the present oy any American commity in quest of statehood. 


\section{BIBLIOGRAPHY}

I. ORICINAI SUUROS:

Salendar of Virginia State Papers (Richmond, 1875-93)

Hlemine, William, "winutes of the First Convention helo at Danville, in the Torritory of Kentucixy, December 27,1784", Louisvjlle lonthly lagazine, Narch, 1789

Ceores Rcgers Clark Papers, 1771-1781, witen by T.A.Tarcs (IIIinois Tistorical Collections, Springfield, Ill.,1912) Volure VIII

Fenine, Villin W., The Statutes of Viretnia (Kiormond, Ve.,18191Eะ3)

Journals of the Continental Congress, 1774-1789 (Washineton, Governnent printing office, 1904)

Tournels of Convontions at Ianville, Ky., 1788-1782 (Photostatic reproouctions of Thomas Todd's minutes of the sixth through the Tenth Conventions) Unpublished at present.

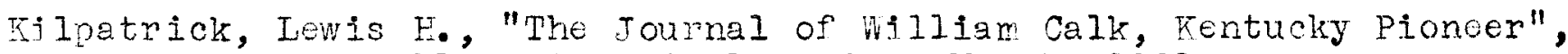
The Mississippl Valley Historical Review, Varch, 1921

Letters enà Other Writings of James Madison (R. Worthington, 770 Broadway, New York CIty) Volume one

Iitte1I, 111 am, The Statute Law of Kentucky (Tomson and Pleasants, Frankfort, $\mathrm{Ky} \cdot, 1810)$ Volume Two

Tưn P.rorton, Louisvilie, Tye,1926) Feprint. Filson Club Publication Number 31

Porcupine, Peter, A Iittie plain English, Addressed to the People of the United States, on the Treaty Negociated with His Britannic pajesty TPhiladeIphia, Thomas Bradford, $1795 \mathrm{~T}$

Robertson, Tames R.,Petitions of the Iarly Inhabitants of Kentucluy (.Tohn P.llorton, Louisville, Ky・, l889) FIIson Club Puolication Tumoer. 27

Richarason, J.B., A Compliation of the Nessages and papers of the Presidents, $1789-1002$ (Washington, D.C., Bureau of Natonal Iiterature anô Art, Igos) 
The Writings of Thomas Tefferson, waited by Paul Ieicester Ford, (New York and Iondon, G.P.Putnam's Sons, 1904-1905

The Writings of James Nonroe, Eaited by S.H.Hamilton (New York, 1898-1903)

The Witings of George Washington, Edited by Tarec Sparks (New York, Harper 8: Brothers, 1847)

The Debates and Proceedings in the Congress of the United States Thashington, D.C.,1834) Volume II

The Kentucky Gazette, 1787,1788,1791 (Reprociuced by the photostat process. In Filson Club Library

Wharton, Francis, The Revolutionary Diplomatic Correspondence of the United States TGovernment Printing office, hashington, D.C., I889) Volume IV

SECONDARY ACCOUNTS:

Bishop, R.E., Outline of the Church in Kentucky containine lieroirs of Davia Rice TLeyingtion, T.T.Skiliman, I824)

Bodley, Temple, our First creat West (John P. Horton, Louisville, Ky.,1938) Filson Club Publication Number 36

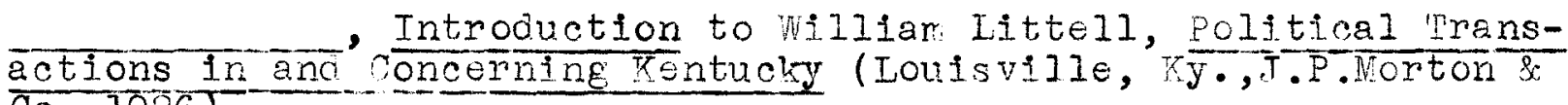
Co.,1926)

Brown, Tohn Mason, The Political Beginnings of Tentucky (Tohn P. Morton, Louisville, Ky.,1889) Filson Club Publication Muber 6

Brown, Tohn P., Old Frontiers (Southern Publishers, Kingsport, Tennessee, 1938)

Cotterill, F.S., "The Cherokee Wars," Dletionary of American History (New Fork, Charles Scrioner's Sons, I940) 
Durrett, Feuoen T., Bryant's Station (John P.irorton, Louisville, $\mathrm{Ky} \cdot$, 1897) Filson Club Puolication Number 12

English, William H., Conquest of the Northwest (Indianapoils, 1896, Bowen-lerr1lj)

Green, Thomas H., The Spanish Conspiracy (Rodert Clark, Cincinnati, Chio, 1891)

IEenry, illiar W. Patrick Henry

Tames, Tames A., The Iife of George Rogers Clark (Chicago,Ill., The University of Chicago Press, 1928)

Lester, Wiliam S., The Transylvania Colony (Spencer, Ind., S.R. Guard \& Co., 1935)

lartin, Asa Earl, The Anti-Slavery Movement in Kentucky Prior to 1850 (Standard Printing, Louisvilie, Ky.,ISI8) Filson CIub Puolication Number 29

Sparks, Tared, The Iife of Gouverneur Vorris (Gray, Boston, Mass., 1.823)

Speed, Thomas, The Wilderness Road (Tohn P. Morton, Lou'svillo, $\mathrm{KJ}$., 1886) Físon Club puidication Mumber 2

Trotn The Political Club, Danville, Kentucky, 1786-1780 Number

Spencer, T.H., A Fistory of Kentucky Baptists, 1769-1885 ( $\mathrm{J} . \mathrm{R}$. Baumes, Cincinnati, Ohio, 1885) Volumes One and Two

Turner, F.J., "Western State-Making in the Revolut1onary Era", American Historical Review, Volume one

Young, Bennett H. History of the Battle of Blue Iicks (John P. Nortor, Iouisville, Ty., 1897)

GUTERAL WOFKS:

Bodley, Temple, History of Kentucky (Chicago-Louisville, The S.J. Clarke Co., 1928) 
Butler, lan, A History of the Commonwealth of Kentucky (wilcox, Dickerman, Louisville, 1834)

Changing, Edward, A History of the United States (Macmillan, New York, 1905)

Collins, Lewis (revised by Collins, Richard H.), History of Kentacky (Covington, Ky., Collins \& Co.,1882) volumes I arid II

Connelley, William E., and Coulter, E. H., History of Kentucky (The American Historical Society, New York, 1922) Volume one

Marshal 1, Humphrey, History of Kentucky (Henry Core, Louisville, $\mathrm{Ky} \cdot, 1812$ ) 